NBER WORKING PAPER SERIES

\title{
IF YOU BUILD IT WILL THEY COME? TEACHER USE OF STUDENT PERFORMANCE DATA ON A WEB-BASED TOOL
}

\author{
John H. Tyler \\ Working Paper 17486 \\ http://www.nber.org/papers/w17486
}

\author{
NATIONAL BUREAU OF ECONOMIC RESEARCH \\ 1050 Massachusetts Avenue \\ Cambridge, MA 02138 \\ October 2011
}

I would like to thank Ben Zhang, Miriam Joelson, David Stern, Max Ashby, and David Storch for for their research assistance, and Amy Wooten, Eric Taylor, Dan Goldhaber, Jeffrey Wayman, and Richard Murnane for helpful conversations and intellectual contributions to this work. I also want to thank the Council of Great City Schools for their generous support for this project. Finally, a particular debt of gratitude is owed to the Cincinnati Public School system and especially to Elizabeth Holtzapple, Director of Research, Evaluation, and Test Administration, and Sarah Trimble-Oliver, Academic and Assessment System Administrator. The views expressed herein are those of the author and do not necessarily reflect the views of the National Bureau of Economic Research.

NBER working papers are circulated for discussion and comment purposes. They have not been peerreviewed or been subject to the review by the NBER Board of Directors that accompanies official NBER publications.

(C) 2011 by John H. Tyler. All rights reserved. Short sections of text, not to exceed two paragraphs, may be quoted without explicit permission provided that full credit, including $\odot$ notice, is given to the source. 
If You Build It Will They Come? Teacher Use of Student Performance Data on a Web-Based

Tool

John H. Tyler

NBER Working Paper No. 17486

October 2011

JEL No. I21

\begin{abstract}
The past decade has seen increased testing of students and the concomitant proliferation of computer-based systems to store, manage, analyze, and report the data that comes from these tests. The research to date on teacher use of these data has mostly been qualitative and has mostly focused on the conditions that are necessary (but not necessarily sufficient) for effective use of data by teachers. Absent from the research base in this area is objective information on how much and in what ways teachers actually use student test data, even when supposed precursors of teacher data use are in place. This paper addresses this knowledge gap by analyzing usage data generated when teachers in one mid-size urban district $\log$ onto the web-based, district-provided data deliver and analytic tool. Based on information contained in the universe of web logs from the 2008-2009 and 2009-2010 school years, I find relatively low levels of teacher interaction with pages on the web tool that contain student test information that could potentially inform practice. I also find no evidence that teacher usage of web-based student data is related student achievement, but there is reason to believe these estimates are downwardly biased.
\end{abstract}

John H. Tyler

Box 1938

21 Manning Walk

Brown University

Providence, RI 02912

and NBER

john_tyler@brown.edu 


\begin{abstract}
The past decade has seen increased testing of students and the concomitant proliferation of computerbased systems to store, manage, analyze, and report the data that comes from these tests. The research to date on teacher use of these data has mostly been qualitative and has mostly focused on the conditions that are necessary (but not necessarily sufficient) for effective use of data by teachers. Absent from the research base in this area is objective information on how much and in what ways teachers actually use student test data, even when supposed precursors of teacher data use are in place. This paper addresses this knowledge gap by analyzing usage data generated when teachers in one mid-size urban district log onto the web-based, district-provided data deliver and analytic tool. Based on information contained in the universe of web logs from the 2008-2009 and 2009-2010 school years, I find relatively low levels of teacher interaction with pages on the web tool that contain student test information that could potentially inform practice. I also find no evidence that teacher usage of web-based student data is related student achievement, but there is reason to believe these estimates are downwardly biased.
\end{abstract}

\title{
1. Introduction
}

Schools and teachers are increasingly being called upon to utilize student performance data in making decisions about policy and practice. Indeed, actors in the K-12 arena are likely to be seen as out of touch and behind the times if they are not engaging in "data driven decision making” or do not claim to be “data driven schools” or “data driven teachers.” As recently as 2005, however, Wayman reported that “...the use of student data for educational improvement has not been widespread. Until only recently, examining student data was a difficult chore for most educators” (Wayman 2005). The recent proliferation of web-based tools to present and assist in the analysis of student performance data has eased this concern and so the questions now turn to how are schools and teachers using the new tools to improve student outcomes. ${ }^{1}$

This paper provides some answers to this question by examining how teachers in one mid-size urban district in the Midwest use a web based tool designed to provide them with

\footnotetext{
${ }^{1}$ The availability of web-based student data tools range from several commercial products now available to districts to systems developed within-house by districts to customized products built to specification by outside vendors. An example of the latter is the New York City school system’s \$180M, five-year agreement with IBM in 2007 to build a system for tracking and analyzing student and school performance (New York Times, March 6, 2007).
} 
student achievement information that can potentially improve their practice. In particular I seek to answer three questions: how much do teachers in the district use the web tool, what types of information do teachers access when they do use the tool, and is usage of web-based student data related to student achievement gains? In addressing these questions this paper is primarily a descriptive study. Nevertheless, solid answers to these questions are critical as the field moves forward in trying to better utilize the vast amounts of student performance that are now collected every year.

This descriptive study is the first that captures and analyzes at a detailed level objective information on teacher usage of student performance data presented through a web based tool. Data for the study come from web logs that are generated each time a teacher logs into the district's web-based tool that is designed to present student data to teachers in user-friendly formats. This system, a data "Dashboard" system, was developed in-house and brought online at the beginning of the 2005-2006 school year. The analysis in this paper is based on web log data from the 2008-2009 and 2009-2010 school years. ${ }^{2}$ For these years I analyze teacher logins to the Dashboard system, the types of pages in Dashboard that teachers view when logged in, the amount of time teachers spend on the different kinds of pages, and whether this activity is related to student test score growth.

A simple theory of action for the way in which teacher usage of student performance data could affect student achievement would have the following sequential components:

1. Test students to gather performance information.

\footnotetext{
${ }^{2}$ For narrative simplicity in the remainder of the paper, I will refer to the 2008-2009 school year as the 2009 school year and the 2009-2010 school year as the 2010 school year.
} 
2. Provide the test results to the teacher in a manner and in formats that foster meaningful analysis.

3. The teacher accesses the test data.

4. The teacher spends time analyzing the test data.

5. The teacher draws knowledge from that analysis that can inform her practice.

6. The teacher knows how and has the ability to alter practice based upon the new knowledge.

7. The teacher acts on the new knowledge and classroom practice is altered.

8. The altered practice has a positive impact on student achievement.

A break down in any one of these steps would prevent the effective use of student test data as in input to instructional improvement and eventual student achievement gains. This project examines the third and fourth steps in the model: do teachers access student performance data and how much time do they spend with the data when it is provided to them? In particular I analyze the extent to which core subject (math, English, social studies, and science) teachers in grades 3 through 8 accessed the performance data of their students via the Dashboard web tool during the 2009 school year. I then use 2010 data to examine changes in usage over a two-year period and to explore the relationship between usage and student performance as measured by their scores on various tests.

In a preview of the findings, the average teacher targeted in the study logged into the Dashboard system just less than once per week during the 2009 school year, and 43 percent of these teachers spent a total of one hour or less during the year viewing Dashboard pages containing test data information on their students (17 percent spent 20 minutes or less during the year on these pages). I also find very little change in usage between the 2009 and 2010 school 
years and no evidence that usage is related to student achievement growth. These relatively low usage levels leave one concerned about the extent to which the average teacher is using Dashboard-presented student test data to inform practice, and the low usage levels also hamper our ability to effectively study the usage-student performance linkage.

The remainder of this paper is organized as follows. In the next section I discuss the literature on teacher use of student performance data. This is followed by a discussion of the data used for this project in section 3 and a presentation and discussion of the results of the analyses of the data in section 4 . Section 5 summarizes and concludes.

The district in this study is a typical mid-sized urban school district, and it has much in common with larger urban districts. There are approximately 35,000 K-12 students in the district and like most urban districts the students tend to come from low income and minority families and student achievement in the district lags behind that of the state as a whole. In the most recent year for which data is available, about 70 percent of the students are eligible for free or reduced price lunch, about 70 percent of the students are African-American, and 25 percent of the students are white.

\section{Prior Research}

The recent push for schools and teachers to use student test data as inputs to decision making rests on a relatively recent and thin research base. Studies of how districts, schools, and teachers utilized data began only about a decade ago and the first research in this area tended to be case studies describing the many ways in which data was being used to support education 
decisions (Pardini 2000; Feldman and Tung 2001; Protheroe 2001; Lachat 2002). ${ }^{3}$ Following this early optimistic assessment regarding the role data could play in assisting school improvement efforts, Ingram, Louis, and Schroeder (2004) used interviews and focus group data from nine schools to caution against assuming that the mere presence of data from standardized tests would translate into the use of that data by schools and teachers. Nevertheless, the increased testing of students combined with the falling price of computing and data storage and the proliferation of data management and analysis tools meant that schools would both be awash in student performance data and subject to pressures to use those data to increase student achievement.

One can get a sense of the rapid growth of the use of education data that was occurring during last decade by looking at looking at the growth in revenue from data management and analysis software and services in the K-12 sector. A 2003 report estimated that between 2000 and 2003 vendor revenues in this area grew from $\$ 98.8$ million to $\$ 145$ million (Stein 2003). This same report ventured that the (then) recent passage of the No Child Left Behind (NCLB) meant that school districts were facing new data reporting challenges that few were prepared to meet, thus suggesting a market ripe for additional investments in data management and analysis tools.

Spurred by both the testing and the reporting requirements of NCLB, and the desire to use student test data for school improvement and student achievement gains, the push was on to develop systems that could store, manage, present, and help practitioners analyze student data. The resulting development and proliferation of software and web-based tools designed to make data analysis both cheaper for districts and more user-friendly for teachers and administrators, helped foster a series of studies of how the field was using data and a focus on the factors that

\footnotetext{
${ }^{3}$ This work is summarized in Wayman, Stringfield, and Yakimowski (2004).
} 
seemed to promote or hinder effective data use. District and school-level surveys, interviews, case studies, focus groups, and ethnographic studies were all employed to better understand what made schools and teachers “data driven” (e.g., Brunner, Fasca et al. 2005; Chen, Heritage et al. 2005; Kerr, Marsh et al. 2006; Marsh, Pane et al. 2006; Datnow, Park et al. 2007; Crawford, Schlager et al. 2008).

A summary of this research falls into three areas. First, the probability of data use by teachers taking hold in a school is increased when a "culture of data use" is developed in the school, when the school has strong leadership that is supportive of teacher use of data, when there is sufficient professional development around data use, when there is allotted time for data use, and when teachers are provided with data systems that are easy to navigate. Second, factors that affect self-reported levels of teacher data use include the timeliness of data that is turned back to teachers, the perceived validity of the test data, and flexibility in the ability to alter instructional practice and pace, particularly vis a vis curriculum pacing guides. Third, at the top of the list regarding how teachers use data are using data to learn about their new students at the beginning of the year, discerning student needs in order to group students for instruction, and determining class-wide strengths and weaknesses for instructional planning.

The most comprehensive information on teacher usage of data comes from the U.S. Department of Education’s National Educational Technology Trends Study (NETTS), surveys administered in 2005 and 2007 to nationally representative samples of teachers each year. In these data the percentage of teachers reporting having access to district student data systems went from 48 percent in 2005 to 74 percent in 2007 (U.S. Department of Education 2008). NETTS respondents also reported a greater likelihood of access to grades and attendance data 
than to student achievement data in 2007, and they expressed a desire for more professional development around data use.

Of the 74 percent of teachers who report having access to student data in 2007, 3 percent reported using data at least once a week for the purpose of identifying skills gaps of individual students so that instructional could be individually tailored according to student needs. Another 15 percent reported engaging in this type of activity at least once or twice a month (U.S. Department of Education 2009). This type of interaction between a teacher and the data of individual students is what many have in mind when they think of using data to improve instruction and increase student achievement.

At this point there is one study in the literature of which I am aware that is based on objective measures of teacher usage. Wayman, Cho, and Shaw (2009) use usage report data from a commercially available tool used by the district in their study. The usage data provided by the system tell us about how many times teachers accessed the system and which sections of the system were accessed. There are, however, limitations to what we learn from this study. For example, we learn from the study that 93 percent of the teachers accessed the Reports section of the tool, the section that contains student performance data. However, given the availability of information from different levels contained in the Reports section (e.g., district, school, ,class, and student), we do not know what percentage of the teachers viewed report data at the individual student level, and importantly, we do not know how much time teachers spent viewing student level data. Nevertheless, the very fact that objective usage measures are being collected and reported is a notable step forward in the field. 
In summary, the availability of student performance data and the tools for using that data have both grown substantially in the last decade. A research base regarding what we think needs to be in place and what needs to occur if teachers are to intelligently use data has also developed apace. Noticeably absent from the research, however, is objective information on how much teachers actually use student achievement data when the hypothesized precursors for teacher data use are in place. This descriptive study is the first to provide detailed information on how much teachers in a given setting actually use computer-resident student test data, how they spend their time when they do access the data, and whether these efforts are related to student achievement gains.

\section{Benchmark Testing, the Dashboard System, and the Resulting Data}

The district in this study has made substantial investments in a system that regularly tests their students in grades 3-8 on Benchmark formative assessments and feeds this test information back to teachers and administrators via the Dashboard tool. For a subset of schools that I will call Targeted Assistance (TA) schools, the district also provides ongoing professional development to teachers on Dashboard use. The 15 TA schools were low-performing schools targeted to receive extra resources beginning in the 2009 school year. All teachers in the district were provided with the opportunity for voluntary, initial training when the Dashboard system was first brought online. In addition to the end-of-year state level assessments, district students in grades 3-8 take four Benchmark assessments through the course of the school year, and students in the $15 \mathrm{TA}$ schools take a pre-test in September and a post-test in January. The Benchmark tests are designed to provide feedback regarding the extent to which district students are making satisfactory progress toward mastering material that will be on the end-of-year state exams. 
Using Dashboard, a teacher can access his students' data on a just-completed Benchmark exam within 24 hours from the time the teacher turns in test results to the district assessment office. Each teacher has access to the complete testing record, current and historical, of every student he is teaching in given year. Teachers cannot view information on students they are not teaching that year. ${ }^{4}$

The Dashboard tool was developed in-house during 2004 and brought online in September of 2005. While the district seems to realize the importance of providing training and support to teachers around Dashboard use, district teachers tend to report uneven amounts of training and support, with some teachers reporting sufficient levels of support and others reporting little support in how to navigate and use Dashboard. ${ }^{5}$ The primary source of training and professional development around Dashboard usage comes from the district's professional development support teams, seven teams of (usually) six individuals—a former principal, a math coach, a language arts coach, a science coach, a social studies coach, and an individual who specializes in special education. The role of the support teams is to "audit schools and assist with academic improvement.” ${ }^{\prime 6}$ Prior to 2009 the support teams worked with all schools and teachers in the district. Beginning in 2009 all five of the teams working at the elementary level were assigned to the fifteen TA schools where one of their primary responsibilities was to help the teachers in these schools utilize Dashboard in ways that would inform and improve their classroom instruction.

\footnotetext{
${ }^{4}$ Dashboard also provides teachers with student level information in areas such as number of absences, number of detentions, etc. I do not analyze teacher usage of this information in this paper.

${ }^{5}$ This information is based on four different focus group discussions with teachers from four elementary schools conducted in December of 2008 by the author and Amy Wooten.

6 Taken from the district's 2006-2001 Strategic Plan.
} 
The district has worked to put in place a connected system of regular student testing, the ability to turn that test data back to teachers in a timely manner via a tool that provides relatively easy access and usability, and district support and encouragement around teacher data use for instructional improvement. Information used in this study to address questions of how much, in what ways, and to what effect teachers use this system derive from the web logs that are generated every time a teacher logs into the Dashboard system. These web logs capture, among other things, the employee id number of the teacher who has logged in, the day and time of the login, the pages that are viewed during each Dashboard session, the sequencing of the teacher's journey through the pages, and information that allows for the construction of the amount of time the teacher spent on each page during the session. Since certain student-related pages also have an associated student id number, I am also able to capture when teachers view the Dashboard data of specific students.

After stripping the data of all personally identifiable information, district administrators supplied me with the universe of raw web log files that were generated from every teacher login that occurred between August 3, 2008 and May 31, 2010. In converting these web logs into analytic data files a key task was coding the Dashboard pages into common groups. Individual pages were grouped into the following page-type categories:

- Class level pages that have information on a given class of a given teacher

- Students-in-class level pages that have information on multiple students in a teacher's class

- Individual-student level pages that have information on an individual student in a teacher's class

- Item pages that have information on particular test items 
- Resource pages that have resource information for teachers such as model lesson plans.

Figure 1 gives an example of a "class" level page for class taught by a hypothetical $5^{\text {th }}$ grade teacher. This page tells the teacher that on the English language arts Benchmark test given on 11/30/2009, her students answered, on average, 44 percent of the questions correctly compared to 39 percent for all the students in her school and 45 percent in the district. Similar statistics for the Benchmark math test are displayed below the language arts results.

$<$ Figures 1-5 about here>

Figure 2 gives an example of a "students-in-class" level page from this same class on the math Benchmark from 11/30/2009. Here the score of each student in the teacher's class is displayed in ascending order down the column. A click on a student, for example Suzie (fictitious name) who got 55 percent correct, would take the teacher to a page with information on Suzie.

Figure 3 gives an example of an "individual student" level page, in this case the page with information on Suzie's responses to all of the questions on the math Benchmark on which she scored 55 percent correct. A click on " 1 " takes the teacher to a page that displays the first question in the Benchmark which, in this case, Suzie answered incorrectly.

Figure 4 gives an example of an "item" level page, in this case the first test item in the aforementioned math Benchmark exam. The item level pages give teachers the exact test question along with the grade level "indicator" and the state "standard" being tested by that question. 
Figure 5 gives an example of a "resource" page in Dashboard. In this case the resource page is a list of the grade level indicators for $5^{\text {th }}$ grade math in Ohio. The bottom part of Figure 5 shows a second resource page which is the page the teacher would be taken to if she were to click on one of the indicators in the graphic above. This second resource page then has links to a model lesson plan to teach that indicator, along with other links to related resources for the teachers.

The pages in Figures 1-5 are meant to be examples of the page type groupings that were created for this analysis. Under each of the groupings (class, students-in-class, individual student, item, and resource) there are many different pages that can be accessed on Dashboard.

In addition to the coding of pages as to page type, other variables that were necessary or convenient for later analysis were created from the raw web logs in the process of converting the web logs into an analytic data file. Following the processing of the web log files, information from district administrative personnel files, course files, and student test files were merged in. ${ }^{7}$

The resulting data files have complete Dashboard usage information on 429 core subject grade 3-8 teachers in 2009 and 359 teachers in 2010. The 2009 data set is a teacher by Dashboard-page panel with 214,779 lines of data that were generated from 14,228 separate logins between August 2008 and May 2009. Similarly the 2009-2010 web logs produce a data set that has 230,323 lines of data generated from 15,655 logins between August 2009 and May 2010. Throughout the study only these core subject grade 3-8 teachers are used. It is in these grades and subjects where students are tested regularly on the Benchmark exams and thus where

\footnotetext{
${ }^{7}$ I thank Eric Taylor for his assistance in the student-teacher matching process.
} 
teachers are expected to use Dashboard on a relatively regular basis to access the performance data of their students.

\section{Results and Discussion}

\subsection{Teacher Use of Dashboard}

A first look at teacher Dashboard usage as captured in the web logs indicates that the average teacher in the targeted group logged into the Dashboard system 33 times during the 2009 school year and spent a total of about 7 hours on Dashboard over the course of the school year. ${ }^{8}$ The average teacher apportioned her 7 hours during the year on Dashboard in the following ways:

- $\quad 3.2$ percent on class level pages

- 26.8 percent on students-in-class pages

- 9 percent on individual student pages

- $\quad 6.6$ percent on item pages

- $\quad 31.6$ percent on resource pages

- 5.2 percent entering student test data information, ${ }^{9}$ and

- $\quad$ 17.4 percent of the time on login, password, or navigational pages containing decision nodes (links) for users, but no information beyond the potential destination pages.

\footnotetext{
${ }^{8}$ The median number of logins was 28 and the median time spent logged into the Dashboard system was about $31 / 2$ hours.

${ }^{9}$ Some of the grade 3-8 teachers also teach in grades K-2 and teachers of these grades enter student test scores directly into Dashboard.
} 
Table 1 gives a more detailed view of how teachers spent time on Dashboard on a per week basis. Panel A give Dashboard login information, with the first row indicating that on average the 429 district teachers logged into Dashboard slightly less than one time per week during the 2009 school year. The second column in the first row indicates that conditional on ever logging in during a week, the average number of logins is about two times per week. The mean time logged in per week across all teachers is about 10 minutes per week, and conditional on having logged in at least once during a week the mean time logged in per week is almost 30 minutes. $^{10}$

<Table 1 about here>

Panel B provides statistics on the extent to which teachers are viewing student test data during the time they are logged into the Dashboard site. Of particular interest is teacher usage of students-in-class and individual student pages, since these are the pages that provide teachers with student test data and test item information. The average teacher spends about 2.3 minutes per week on students-in-class pages and slightly over half a minute per week on individual student pages. Among teachers who spend any time on these pages during the week, the mean times are 7.6 minutes on students-in-class pages and 6.33 minutes on individual student pages. The average teacher accesses (hits) a students-in-class page about 2.5 times per week and an individual student page only about once every two weeks (0.58 times per week). Panel C provides similar statistics for item and resource pages.

\footnotetext{
${ }^{10}$ Note that the 30 minutes online could be accumulated in one or more than one Dashboard sessions during the week.
} 
As reported earlier, Wayman, Cho, and Shaw (2009) found that 93 percent of the teachers in their study district accessed the Reports section of the student data tool, the section containing information on student performance. A comparable measure on Dashboard is the percent of teachers who accessed a class, students-in-class, or individual student page at least once during the year. That figure is 98 percent.

Another comparison that can be made is to the previously cited figures from NETTS of 3 percent of the surveyed teachers who reported using individual student data at least once weekly and 15 percent who reported doing so at least once a month (U.S. Department of Education 2009). I too find that about 15 percent of the teachers are observed accessing individual student pages on Dashboard at least once a month. There are, however, no teachers in the Dashboard data who are observed accessing individual student pages at least once a week throughout the year.

There are two ways that teachers can use Dashboard to access student test data. They can view the information online, the focus of the analysis thus far, or they can use Dashboard to print out student test data information. Panels D and E of Table 1 provide information on this latter method of interacting with Dashboard. On average teachers go to pages that print students-inclass information only about once every three weeks ( 0.35 times per week), and they go to pages that print individual student information only once every 6 weeks (0.16 times per week). These print statistics suggest that teachers use Dashboard more as an interactive tool than as a tool for printing off student test data.

While the usage statistics in Table 1 are suggestive regarding the extent to which and the ways in which teachers use Dashboard, we can get a better sense of teacher usage by looking at 
patterns of teacher usage by week throughout the year. Figure 6 provides information on the pattern of Dashboard logins by district teachers during the 2009 school year. In Figure 6 and figures that follow, key test dates are marked with vertical lines: blue for the Fall pretest given to the 15 TA schools, green for each of the four Benchmark tests given during the year, maroon for the January posttest given the TA schools, and red for the end-of-year state tests. Following each test a two week period is shaded in with the corresponding color. This two week period represents the period during which test results from that test will be appearing on Dashboard, with the results for most classes available within two weeks of the test administration. ${ }^{11}$

Figure 6 shows variation through the year in the percentage of teachers who login to Dashboard during the week. In particular, Figure 6 suggests higher percentages of teachers logging into Dashboard in the weeks following a Benchmark assessment than at other times during the year, ranging from about 45 percent on the Fall pretest and the $1^{\text {st }}$ Benchmark to slightly over 70 percent of the logging in immediately after the last Benchmark in March.

Figure 7 gives weekly information on the median time spent logged in per week, among teachers who ever logged in during that week. Except for just before and just after the final Benchmark in March, all of the median login times in Figure 7 are around or less than 10 minutes per week. $^{12}$

\footnotetext{
${ }^{11}$ Following a Benchmark test the teacher turns the test sheets into district central office where they are scanned for scoring and posted to Dashboard within 24 hours. Teachers are responsible for scoring the relatively few openresponse test items of their students and this can sometimes cause a delay in getting the tests in to central office. Also, a teacher may delay turning in test sheets to allow a student who was absent a chance to take the Benchmark test upon return to school. Results from the end-of-year state test require longer since they have to be sent to the state for scoring before being returned to the district. They will not be available within two weeks of test administration.

${ }^{12}$ Mean login times range from close to zero during the middle of October to about 40 minutes in the week following the last Benchmark.
} 
Figures 6 and 7 provide information on how much teachers use Dashboard, and a glance at these figures suggests that on any given week somewhere around 10 to 40 percent of the district teachers we are studying logged into the system that week and that the "average" teacher who logged in spent somewhere around 6 to 8 minutes online with Dashboard during the week. One way to think about whether this represents substantial usage of student data is to consider two elementary school teachers who each have self contained classrooms of, say, 21 students. Assume that one-third of each teacher's students are struggling and that Benchmark tests have just been administered. With 50 percent or fewer teachers logging in each week according to Figure 6, we can assume that only one of the two teachers would go to Dashboard to get information that might help her with her seven struggling students, and Figure 7 suggests that the teacher who did turn to Dashboard for information spent only about one minute per struggling student logged into the system (7 struggling students and a median login time of around 7 minutes per week for those who ever logged in that week). While only a rough barometer, this back-of-the-envelope estimation suggests that the average teacher may not be making extensive use of Dashboard as a tool for helping their struggling students.

A second question pursued in this project is how do teachers use Dashboard, and in particular, to what extent do teachers view student test data information? Since the bulk of student test data is presented on either students-in-class pages or individual student pages, the focus on teacher usage will now turn to those pages. Figure 8 displays information on the mean amount of time teachers spent each week viewing Dashboard students-in-class pages. Averaged across all teachers, including those who never logged on during the week, Figure 8 indicates that on average teachers spent from one to four minutes per week viewing students-in-class pages, with the exceptions of 6 and 9 minutes per week spikes after the $2^{\text {nd }}$ and $4^{\text {th }}$ Benchmark tests. 
Under a model where more intensive Dashboard usage is represented by teachers who "burrow” deeper down in Dashboard to the level where test data on individual students is presented, the information in Figure 9 is somewhat discouraging. In Figure 9 the average teacher in the sample spends less than 2 minutes per week viewing individual student pages, even during peak weeks. As we learned earlier in Table 1, the mean time per week spent on individual student pages is only 0.6 minutes per week for all teachers, and 6.33 minutes per week for all teachers who viewed an individual student page in a given week. There is a long right-hand tail to the conditional distribution, however, as the median time on individual student pages among those with non-zero values in a given week is only 1.4 minutes, and the $25^{\text {th }}$ percentile is half a minute. These statistics and Figure 9 suggest that the bulk of teachers rarely spend substantive amounts of time on Dashboard viewing performance data at the individual student level.

Figure 10 provides information on how teachers apportion their time on Dashboard between viewing student level information and using the web-based tool for other purposes such as looking at lesson plans or reviewing state standards. According to Figure 10, teachers who login to Dashboard spend from 20 to 50 percent of their time looking at student performance data, figures that seem reasonably high given all of the other types of information a teacher can access on Dashboard. Thus, concerns about how much teachers are using student performance data on Dashboard to inform and improve their practice should focus more in whether they login at all and how much time they spend while logged in, rather than in what they are doing while they are on Dashboard.

As mentioned earlier, one issue that might cloud our understanding of how teachers use student performance data to inform their practice and how they utilize the Dashboard tool in this endeavor is the extent to which teachers use Dashboard as a tool for accessing and printing out 
performance data. Simply put, if teachers login, print, and log out of Dashboard then focusing on time-on-page will substantially underestimate Dashboard usage of student performance data. However, supporting what we learned in Table 1, Figure 11 suggests that teachers' primary use of Dashboard is as an interactive tool rather than a printing tool. In every week of the school year the number of "viewing" hits by teachers on students-in-class and individual student pages easily dominates the number of "printing” hits on these pages.

Figure 12 summarizes the information thus far about the extent to which teachers use Dashboard to view and analyze student performance data. Figure 12 displays the distribution of total time during the year spent by teachers on students-in-class and individual student pages combined. According to this figure 17 percent of the core subject grade 3-8 teachers 2009 (73 of 429 teachers) spent a total of 20 minutes or less during the entire school year viewing these types of pages and 43 percent of the teachers (187 out of 429) spent an hour or less during the year on these student level pages. There is a long right hand tail to this distribution, however, and a third of the teachers spent more than two hours during the year on these pages and 20 percent spent more than three hours

\subsection{Correlates of Dashboard Use}

The ability to link other district data sources to the Dashboard web log information allows for the examination of the correlates of Dashboard use. District personnel files are used to obtain information on teacher characteristics such as gender, race/ethnicity, years of experience 
teaching, education level, and salary. ${ }^{13}$ District student and course files are used to match students and their test scores to teachers and construct value-added measures for teachers and measures of average class achievement at the beginning of the year.

Table 2 shows the results from OLS regressions of the natural log of the sum of total time spent during the year on students-in-class and individual student pages on a set of class and teacher characteristics including:

- the baseline mean achievement level of the teacher's students at the beginning of the year along with an indicator for whether the baseline level was imputed, ${ }^{14}$

- teacher value-added,

- $\quad$ an indicator for whether a teacher taught in grades 3 through 6 relative to grades 6 through $8,^{15}$

- indicators for gender and race/ethnicity, years of teaching experience, and indicators for education level.

The estimates in Table 2 are based on the 325 teachers who have non-missing values on all of the variables in the model. ${ }^{16}$ In the first column of the table the only statistically significant predictors of total time spent during the year viewing student level pages are the prior

\footnotetext{
${ }^{13}$ Even though annual salary is in the data, because it is essentially determined by years of experience and education level, we use these other variables in regression models instead of salary.

${ }^{14}$ This baseline measure was computed by averaging, for each student, the prior year's state exam math score and state exam reading score (both mean zero, standard deviation one variables), and then averaging these scores across the students in a teacher's class.

${ }^{15}$ The dummy variable indicator equaled one for the 311 teachers who taught in any configuration of grades 3 through 6 , and zero for the 9 teachers who taught in a grade 6 through 8 configuration and zero for the 89 teachers who taught in grades 7 or 8 or a grade 7 and 8 combination.

${ }^{16} 409$ teachers have non-missing values on all variables except for value-added. When the models in Table 2 are fit over these teachers and value-added is excluded as a predictor, the results, available from the author, are essentially unchanged.
} 
achievement level of the class and the grade level indicator. Teachers in higher performing classes tend to view student level Dashboard pages less frequently, and teachers in grades 3-6, traditional elementary grades, view student data on Dashboard at lower rates than teachers in middle school grades.

$<$ Table 2 about here $>$

Estimates from a school fixed effects model are in column 2. Within schools it is no longer the case that the data of students in higher performing classrooms is viewed at lower rates, but the lower viewing rates of elementary teachers remains. With a mean total time spent on the two types of pages of about two hours during the course of the year (mean $=122.0$ minutes with standard deviation $=137.2$ ), teachers who taught in grades 3 through 6 spent about 36 percent less time viewing these student level pages than did observationally similar teachers who taught in middle schools or taught middle school grades in combined-grade schools though this estimate is only marginally significant in the school fixed effects model. ${ }^{17}$

Following up on the time dependence of Dashboard usage depicted in Figure 8, Table 3 presents estimates from models fit to a teacher-week panel that included indicator variables for whether a given week in the school year was a week before a Benchmark or state test, within two weeks after a Benchmark or state test, or the week when the Benchmark or state test was administered. The excluded time category is any "off test” week that is not in one of the before, during, or within two weeks after test intervals.

<Table 3 about here $>$

${ }^{17}$ Calculated as $\exp (-0.304)-1$. 
Estimates in column 1 indicate that teachers are not spending more time per week viewing student level pages in Dashboard in the week just prior to a Benchmark test than during the "off test” weeks. In fact they spend about 13 percent less time in any week before a Benchmark than they do during any “off test” week. Teachers do, however, spend more time viewing student level pages in the two weeks after a Benchmark test. They spend about 50 percent more time per week in the two weeks just after a Benchmark test than during the "off test” weeks. ${ }^{18}$ The estimates in the first column also indicate that teachers spend less time during and after the state exams than during “off test” weeks.

The second and third columns of Table 3 explore the extent to which the timing of teachers' use of Dashboard to view student level pages can be explained by average class ability and teacher characteristics (column 2) or by school fixed effects (column 3). The estimates from these specifications are very similar to those of the basic model in column $1 .{ }^{19}$

\subsection{Change Over Time in Usage}

The evidence thus far is that teachers spent relatively little time in 2009 viewing studentlevel performance data on Dashboard. To examine whether these patterns of usage changed between 2009 and 2010 the weblog data from 2010 are utilized. Summary statistics for the 359 core subject grade 3-8 teachers in 2010 are similar to those in Table 1 that are based on the 2009 teachers. The only difference is evidence that teachers in 2010 spent some more time viewing

\footnotetext{
${ }^{18}$ Calculated as $\exp (0.436)$ - 1

${ }^{19}$ I note that the low viewing rates during and following the state exams is not surprising since this is the end of the school year and teachers will not have yet gotten back the state exam results.
} 
students-in-class pages than did teachers in 2009. On average, 2010 teachers spent 117.3 minutes looking at students-in-class pages versus the 97.4 minutes teachers spent on these pages in 2009 (p-value of the difference is 0.022). There is no statistical difference in the mean total time for the year viewing individual-student pages (27.1 minutes for 2010 teachers versus 25.2 minutes for 2009 teachers, $\mathrm{p}=0.611$ ). Similarly, the 2010 teachers printed out more students-in-class pages than did the earlier teachers (23.1 pages for the year versus $14.7, \mathrm{p}=0.000$ ), but there was no difference in the printing of individual-student pages (8.5 versus 6.7, $\mathrm{p}=0.173)$.

In addition to these aggregate statistics, there are 243 teachers who are observed in both years in the data. Using these teachers we can examine within-teacher changes over time in Dashboard usage of student-level data. The results in Table 4 are from teacher fixed effects models that control for any changes across the years in class size and average class ability as measured by the average class scores on the previous year's state exams. The dependent variables in models 1 and 2 measure log teacher time spent on students-in-class (column 1) and individual-student pages (column 2), while the dependent variables in models 3 and 4 measure log number of times students-in-class or individual-student data was printed. Results in the first two columns reinforce the aggregate statistics and suggest that the observed changes in mean time viewing students-in-class pages is primarily a within-teacher change rather than a compositional change in teachers across the years. On the other hand, the marginally significant estimates on the 2010 indicator in column 4 suggest that the aggregate statistics may mask within-teacher increases in the number of times individual-student level pages were printed out between 2009 and 2010. Also, column 3 indicates that teachers in TA schools tended to print out students-in-class information at higher rates in 2010 than in the previous year and at higher rates than teachers in non-EI schools. 
$<$ Table $4>$

The fixed effects estimates in Table 4 show some areas where teachers increased Dashboard usage between 2009 and 2010. Overall, however, there is no robust evidence of systematic increases in Dashboard usage across the years.

\subsection{Dashboard Usage and Student Test Score Gains}

Ultimately we are interested in the extent to which teacher usage of student performance data is related to student achievement gains. I use the 2010 data that has both state exam and Benchmark score data to explore this question, and since the interaction that matters occurs when a teacher views the data of a particular student, I first use these data to examine the predictors of that happening.

In the 2010 data, 309 of the 359 teachers viewed the Dashboard data of one or more of their students at least once during the year. Of these 309 teachers, 271 of these teachers can be matched to the value-added distribution in the district, have non-missing information in the personnel files, and have at least one student who can be matched to the test score file. These teachers are matched to 4,106 unique students in fitting the following models that explore the correlates of teacher usage of individual student data:

$$
\begin{aligned}
& Y_{i j}=\beta^{*} \text { pre-test }_{i j}+f\left(X_{i j}\right)+g\left(W_{j}\right)+\varepsilon_{i j} \\
& Y_{i j}=\beta^{\prime}{ }^{*} \text { pre-test }_{i j}+f\left(X_{i j}\right)+\alpha_{j}+\eta_{i j}
\end{aligned}
$$


where $i$ indexes students and $j$ indexes teachers and the dependent variable is the log of the total time teacher $j$ viewed the data of student $i$ on Dashboard during 2010. As before, the student pretest score is the average of the previous year's state exam scores in math and English language arts (ELA). For the few students who did not have both scores to average, the available math or the ELA score was used. ${ }^{20}$ The vector $X$ contains student characteristics that might be predictive of $Y$ and in this case include indicators for eligibility in the district's gifted and talented programs, whether a special education student, and whether designated as an English language learner. ${ }^{21}$ The vector $W$ is composed of teacher characteristics including value-added score, gender, race, years of experience in the district, grade taught in 2010, education level, and whether or not a national board certified teacher. Equation 2 replaces the teacher characteristics with a teacher fixed effect.

Results from estimating equations 1 and 2 are in Table 5 . The only variables that are consistently predictive of teacher use of a student's Dashboard data are the prior year's state test score and special education status, with teachers viewing the data of students who started the year at lower achievement levels at higher rates, and also viewing the data of special education students at higher rates. Estimates from the teacher fixed effects model in column 3 indicate that given two students in the same teacher's class who were one standard deviation apart in terms of their pre-test scores, the teacher viewed the Dashboard data of the lower achieving student about 5 percent more than the data of the higher achieving student. That same teacher also viewed the

\footnotetext{
${ }^{20}$ There were 22 students with only prior test scores in math and 30 students with only prior ELA scores.

${ }^{21}$ The data also contain information on gender and race/ethnicity, but these are not included in the model since conditional on pre-test score they should not be theoretically linked to a teacher's use of student data. Also, these variables are never statistically important when they are included.
} 
data of her special education students at a 21 percent higher rate. ${ }^{22}$ In this model it is also the case that the data of English language learners was also viewed at a higher rate. While statistically significant, these estimates must be put in context. The mean total time spent viewing a random individual student in 2010 was about two minutes and twenty seconds. Thus, even the 16 percent higher rate of viewing the data of special education students translates into only about an extra 20 seconds per year on average that teachers spent on special education versus non-special education students. Nevertheless, these results—-more time spent on lower achieving and special education students_-are consistent with where we might predict a teacher would spend their Dashboard time. ${ }^{23}$

\section{$<$ Table 5>}

The study now turns from exploring what predicts teacher usage of individual student data to whether that usage is related to increased student achievement. Absent exogenous variation in the amount of time teachers spend viewing student Dashboard data, developing a satisfactory model relating teacher Dashboard usage to student achievement growth is not a straightforward exercise. To see this consider the following model:

$$
A_{i j t}=\beta^{*} A_{i j, t-1}+\delta^{*}\left(T_{i j t}\right)+f\left(X_{i j t}\right)+g\left(W_{j t}\right)+\varepsilon_{i j t}
$$

where $i, j$, and $t$ index students, teachers, and time respectively. $A$ is a measure of achievement and, as before, $X$ and $W$ (in equation 3) are vectors of student and teacher characteristics, though the $X$ vector in these achievement equations also contains information on the gender and

\footnotetext{
${ }^{22}$ Calculated as $\exp (0.158)-1$.

${ }^{23}$ Similar results available from the author are obtained in models where the dependent variable is an indicator for ever printing out Dashboard data on student $i$ during the year.
} 
race/ethnicity of the student. $T$ is a measure of the amount of time that teacher $j$ spent viewing the Dashboard data of student $i$ between period $t-1$ when a prior measure of achievement was gathered and time $t$. As before, we could also consider a model such as equation 4 where the vector of teacher characteristics is replaced with a teacher fixed effect, $\alpha$.

$$
A_{i j t}=\beta^{*} A_{i j, t-1}+\delta^{\prime} *\left(T_{i j t}\right)+f\left(X_{i j t}\right)+\alpha_{j}+\varepsilon_{i j t}
$$

The parameters of interest in equations 3 and 4 are $\delta$ and $\delta$, measures of the relationship between time spent viewing a student's data and student achievement growth.

A priori, one would expect $\delta$ to be non-negative since viewing a student's Dashboard data should not lead to a decrease in achievement. However, a concern in estimating $\delta$ in this model is that teachers likely use information unavailable to the researcher in making decisions about the use of student performance data on Dashboard. In particular, consider two observationally similar students who have equal levels of prior achievement. If one of these students is having more academic problems during the year than the other and these unobserved (in the data) problems are positively correlated with a teachers time viewing that student's data, then estimates of $\delta$ would be downwardly biased. Nevertheless, lacking suitable instruments for $T$, I estimate equations 3 and 4 using the available data.

Equations 3 and 4 are first estimated using the end-of-year state exams as measures of prior and final student achievement. In these models $t-1$ is the end of the 2009 school year and time $t$ is the end of the 2010 school year. Thus, $T$ represents the total time that teacher $j$ spent on student $i$ 's Dashboard data during the 2010 school year. In these models the estimate of $\delta$ based on equation 4 is 0.0008 (s.e. $=0.001)$ and the estimate from the fixed effects model of equation 5 
is even closer to zero. ${ }^{24}$ From these estimates we would conclude that either teacher usage of Dashboard is unrelated to student achievement growth or that the estimates are biased toward zero.

A more proximate measure of student achievement available in the data comes from student test scores on the quarterly Benchmark assessments. In models using Benchmark test scores the immediately prior Benchmark test is used as the measure of prior achievement for each subsequent Benchmark except in the case of the first Benchmark of the year where prior achievement is measured by the previous year's state exam score. In the Benchmark test model the measure of $T$ is teacher time on the Dashboard data of student $i$ in the interval between the current Benchmark exam and the prior measure of achievement. ${ }^{25}$ When fitting the Benchmark test models only students in grades 3,4 , and 5 who are observed as having only one teacher are used. With this subsample of students and teachers one can be more certain that all of the activity that is occurring between a teacher and a given student's Dashboard data is being captured. In this sample there are 1,535 students across 149 grade 3-5 teachers with at least one math Benchmark score and 1,530 students across 150 teachers with at least one ELA Benchmark score.

Before turning to estimates of equations 3 and 4, Figures 13 (for math) and 14 (for ELA) display scatter plots of the Benchmark scores versus teacher time on Dashboard. Each point on either graph represents the Benchmark score of an individual student graphed against the time

\footnotetext{
${ }^{24}$ Estimates on the other variables in the models are generally as expected (e.g., eligibility for gifted and talented programs is positively related to achievement growth, special education designation is negatively related, and prior achievement is the strongest predictor of current achievement). None of the observed teacher characteristics in $W$ are statistically significant. Full regression results available from the author.

${ }^{25}$ In the case of the first Benchmark $T$ is measured by teacher Dashboard use between the beginning of school and the first Benchmark.
} 
spent by the teacher viewing the data of that student in the interval between the prior and current Benchmark test. Any given student will be represented by from one to four data points depending upon the number of Benchmark tests for that student in the data. ${ }^{26}$

Figures 13and 14 certainly do not suggest a relationship between the Dashboard usage and Benchmark scores. Moreover, these figures also highlight yet again the limited usage of Dashboard by teachers for viewing student data. The great bulk of the data is massed at very low levels of time spent on Dashboard. While the mean of time spent on a student in any given interval between Benchmark tests is just less than half a minute (0.45 with s.d. = 2.07), 74 percent of the 6,279 student-Benchmark-intervals have a value of zero for the time spent by the teacher viewing student-level data.

Estimates of equations 3 and 4 using Benchmark test scores as the achievement level are presented in Table 6, and they bear out the graphical information in Figures 13 and 14. As with the state test score estimates, in none of the models is the time spent on Dashboard in a Benchmark-interval related to the subsequent Benchmark test score. ${ }^{27}$ The poorly estimated negative point estimates of $\delta$ suggest the possible presence of downward bias due to unobserved heterogeneity. In any case, there is no evidence in any of the models used to estimate equations 3 and 4 that Dashboard usage of student performance data leads to student achievement gains.

$<$ Table 6>

\footnotetext{
${ }^{26}$ For example, among the observations that will be used in the estimates, there are 1,540 students with math scores in the first Benchmark interval, 1,539 in the second, 1,542 in the third, and 1,367 in the fourth. The numbers are very similar for ELA scores.

${ }^{27}$ In addition to fitting versions of equations 3 and 4, I also use the fact that there are up to four Benchmark exams for each student to fit a student fixed effects model. The results in these models, available from the author upon request, are very similar to the estimates in Table 6.
} 
There is a notable pattern of Dashboard usage in the district that may help explain some of the null results in Table 6. If teachers were using Dashboard throughout the year as a tool for promoting student achievement, we would expect to observe teachers viewing the data of their students at various times during the year. Instead, it is the case that one of every three teachers used in the Benchmark test analysis spent all of their time viewing individual student data in one of the four possible Benchmark test intervals, and they spent no time during any of the other intervals. ${ }^{28}$ Also, across teachers who concentrate all of their time in one interval, no interval tends to have more teachers than other intervals. These patterns suggest that something other than data use for instructional purposes is driving teacher usage of Dashboard, at least when it comes to viewing data on individual students. For example, it may be that teachers only look at the data of their individual students when prompted by campus principals or district professional development staff, or as a function of the district's teacher evaluation system. Unfortunately, these data have no information that would allow us to better understand this pattern.

\section{Summary and Conclusions}

This paper has drawn upon unique data to present some of the first detailed objective estimates of how much and in what ways teachers actually use web-based student performance, and the extent to which such use might be related to student achievement. Though primarily descriptive in nature, the information in this paper should help to fill a void in our understanding of how student performance data might inform and improve classroom practice. It is obvious that teachers must first access student performance data if these data are to be used in ways that can

\footnotetext{
${ }^{28}$ Also, 51 percent of the teachers spent 75 percent or more of their time in just one of the intervals.
} 
inform practice and improve student achievement. To date there has been limited information on this critical step, a knowledge gap this paper addresses.

While there is no other district against which to compare the teacher usage statistics from the district used in this study, it is fair to say that the results from this district are less than encouraging. Three years after the launching of the Dashboard system, and well into a substantial district efforts encouraging teacher use of Dashboard, measures of teacher usage of student data are relatively low. On average, teachers targeted by the district as the primary group to use student performance data—core subject teachers in grades 3-8—view pages with student level information about 3 minutes per week. Perhaps more telling, the average teacher in this group views information at the individual student level an average of only 36 seconds per week during the course of the school year. Furthermore, a close examination of the data indicates that one in three teachers spent all of their limited time viewing data on their individual students at only one point during the year, never visiting their student data on Dashboard at any other time. The levels and patterns of observed usage give little indication of systematic use of student performance data on Dashboard by district teachers.

Focus group research conducted in the district during the two years of this study suggests some reasons that teacher usage of Dashboard may be sub-optimal. Teachers in these meetings were quite candid in expressing their opinions about and experiences with Dashboard. One factor that arose with relative frequency was an expressed concern that the Benchmark tests lacked some validity because they often tested material that the teachers had yet to cover in class. A second factor that was supported across several focus group discussions was a perceived lack of instructional time to act on information that a teacher might gain from Dashboard data. In particular, teachers expressed frustration with the lack of time to "reteach" topics and concepts to 
students that had been identified on Dashboard as in need of "reteaching" based on their performance on a given indicator. A third concern was a lack of training in how to use Dashboard effectively and efficiently. A fourth common barrier to Dashboard use cited by teachers was a lack of time for Dashboard-related data analysis.

Regarding this last point, in spite of the investment in the student testing and data provision system of which Dashboard is central, it is not clear what model the district has in mind when it comes to time use and teacher interaction with Dashboard. If teachers are now expected to spend time analyzing student performance data relative to how they were spending time in a pre-Dashboard era then either:

1. the district expects time-saving efficiency gains from Dashboard such that time spent on Dashboard during the work day makes other essential tasks less time consuming,

2. the district expects teachers to reallocate time from other tasks that are now deemed as non-essential to spending time on Dashboard,

3. the district feels that there is slack time during a teacher's work day that can be used for Dashboard data analysis, or

4. the district expects teachers to analyze Dashboard data during out-of-school time.

An articulation by district leaders regarding which of the above scenarios is the one they envision could help define future priorities and provide greater teacher buy in. In the meantime, if teachers anticipate that the district has an unarticulated scenario \#4 in mind, then it is unlikely that data analysis on Dashboard will ever be a significant factor in informing a teacher's practice 
even if all of the supposed precursors of effective data use such as good building leadership, district support and encouragement, a good data analysis tool, etc., were in place.

This study should provide a cautionary note to districts that are investing in systems designed to bring student performance data to teachers via regular testing and web-based data presentation and analytic tools. The evidence from this study is that one should be careful in assuming how much teachers may actually base their teaching on the evidence that comes from a even a carefully designed system that tests students and then provides that data to teachers as inputs to their instructional practice. 


\section{References}

Brunner, C., C. Fasca, et al. (2005). "Linking Data and Learning: The Grow Network Study." Journal of Education for Students Placed At Risk 10(3): 241-267.

Chen, E., M. Heritage, et al. (2005). "Identifying and Monitoring Students' Learning Needs with Technology." Journal of Education for Students Placed At Risk 10(3): 309-332.

Crawford, V. M., M. S. Schlager, et al. (2008). Supporting the Art of Teaching in a Data-Rich, High-Performance Learning Environment. Data-Driven School Improvement: Linking Data and Learning. E. B. Mandinach and M. Honey. New York, Teachers College Press: 109-129.

Datnow, A., V. Park, et al. (2007). Achieving with Data: How High-Performing School Systems Use Data to Improve Instruction for Elementary Students. Los Angeles, CA, Center on Educational Governance, University of Southern California.

Feldman, J. and R. Tung (2001). "Using Data Based Inquiry and Decision-Making to Improve Instruction." ERS Spectrum 19(3): 10-19.

Ingram, Debra, Karen R. S. Louis, and Roger Schroeder. (2004). "Accountability Policies and Teacher Decision Making: Barriers to the Use of Data to Improve Practice." Teachers College Record 106(6): 1258-1287.

Kerr, K. A., J. A. Marsh, et al. (2006). "Strategies to Promote Data Use for Instructional Improvement: Actioins, Outcomes, and Lessons from Three Urban Districts." American Journa of Education 112(August): 496-520.

Lachat, M. A. (2002). Data-Driven High School Reform: The Breaking Ranks Model. Providence, RI, Northeast and Islands Regional Educational Laboratory at Brown University.

Marsh, J. A., J. F. Pane, et al. (2006). Making Sense of Data-Driven Decision Making in Education: Evidence from Recent RAND Research. Washington, D.C., RAND Corporation.

Pardini, P. (2000). "Data, Well Done." Journal of Staff Development 21(1): 12-18.

Protheroe, N. (2001). "Improving Teaching and Learning with Data Based Decisions: Asking the Right Questions and Acting on the Answers." ERS Spectrum 19(3): 4-9.

Stein, M. (2003). Making Sense of the Data: Overview of the K-12 Data Management and Analysis Market. Boston, MA, Eduventures, Inc. 
U.S. Department of Education, Office of Planning, Evaluation, and Policy Development (2008). Teachers' Use of Student Data Systems to Improve Instruction: 2005-2007. Washington, D.C.

U.S. Department of Education, Office of Planning, Evaluation, and Policy Development (2009). Implementing Data-Informed Decision Making in Schools--Teacher Access, Supports, and Use. Washington, D.C.

Wayman, Jeffrey C., Cho, and Shaw (2009)

Wayman, Jeffrey. C. (2005). "Guest Editor's Introduction." Journal of Education for Students Placed At Risk 10(3): 235-239.

Wayman, Jeffrey. C., Sam Stringfield, and Mary Yakimowski. (2004). Software Enabling School Improvement Through Analysis of Student Data. Balitomore, MD, Center for Research on the Education of Students Placed At Risk, The Johns Hopkins University. 
Figure 1. Example of a “class” level page from Dashboard.

\section{Percent Correct \\ Public Schools Dashboard \\ Demo School \\ Teacher: Demo Teacher \\ Section: \\ Test Date: $11 / 30 / 09$}

Printer Friendly

Version

Average Percent Correct - Language Arts

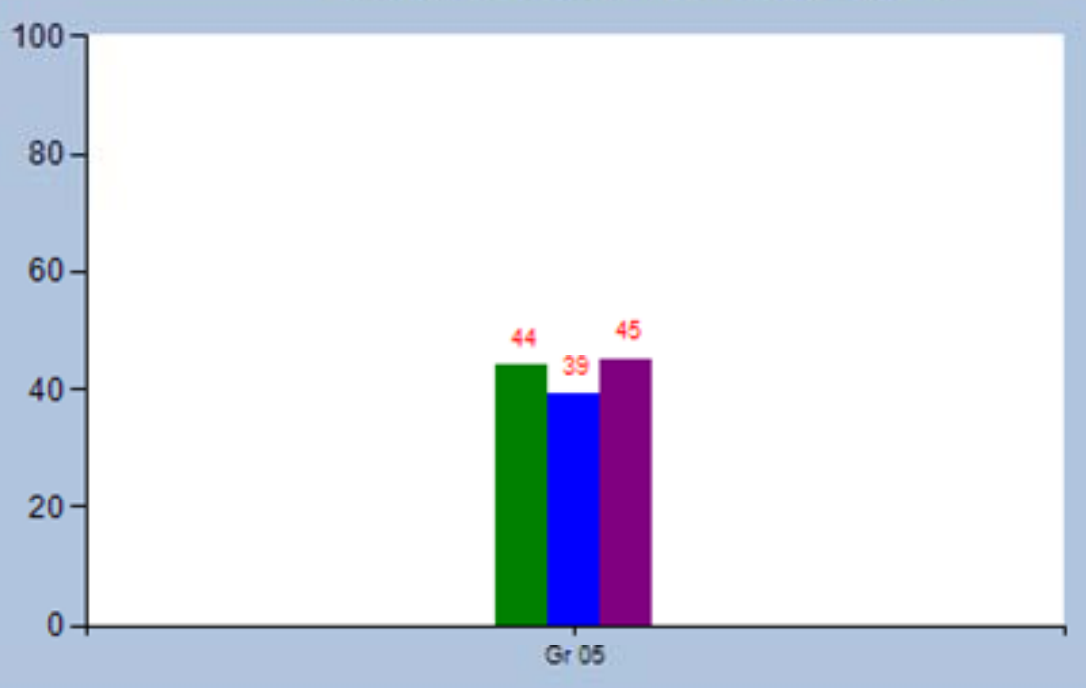

Average Percent Correct - Math

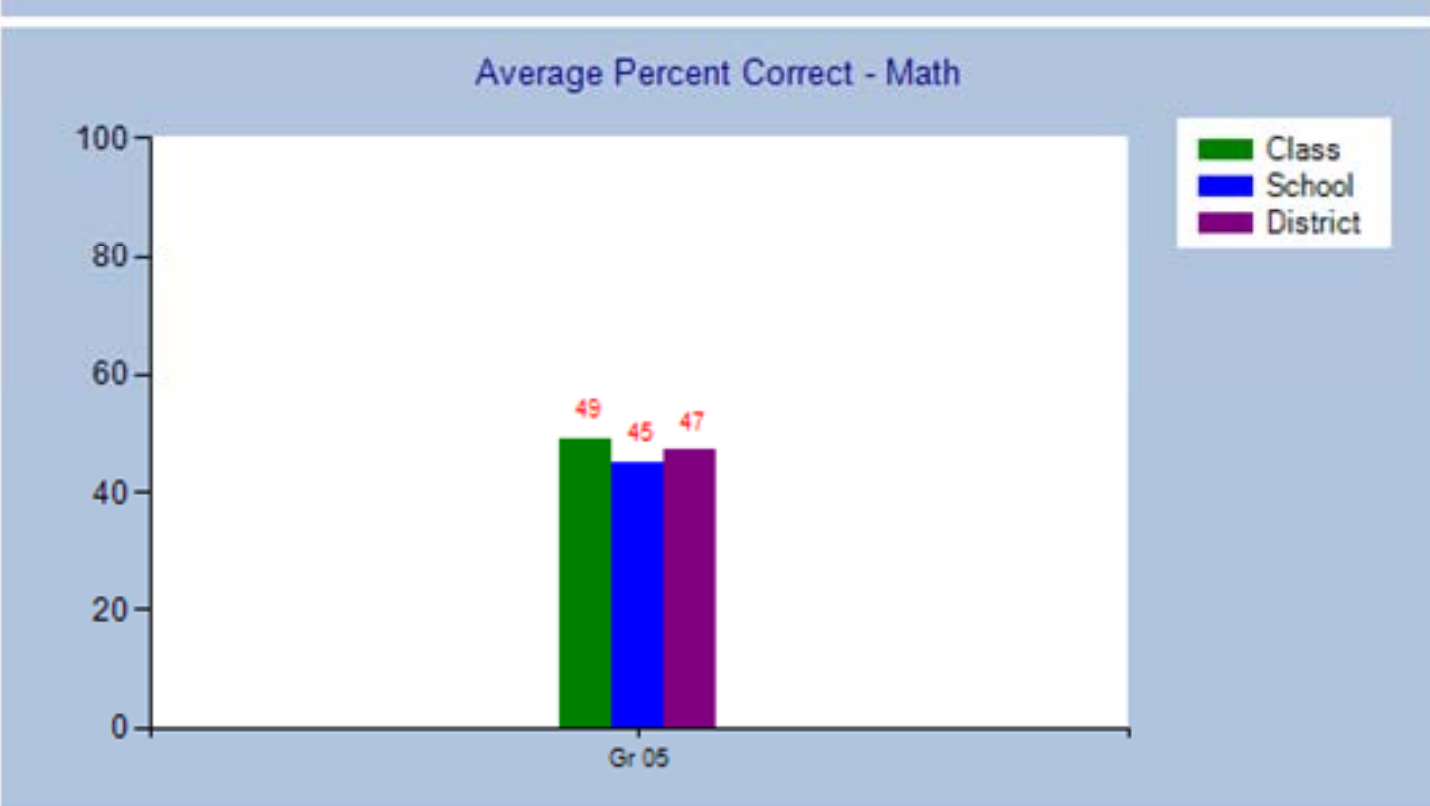


Figure 2. Example of a "students” level page from Dashboard.

\section{Percentage Correct}

Public Schools Dashboard School: Demo School

Teacher: Demo Teacher

Section:

Test: Benchmark Assessment B2, Grade 5 Math (2305)-11/30/09

Avg \% Correct: $49 \%$

District Avg \% Correct: $47 \%$

Graphs showing all district, school, class averages:

\begin{tabular}{|c|}
\hline Student and Score \\
\hline$(29 \%)$ \\
\hline$(29 \%)$ \\
\hline$(31 \%)$ \\
\hline$(33 \%)$ \\
\hline$(38 \%)$ \\
\hline$(38 \%)$ \\
\hline$(48 \%)$ \\
\hline$(48 \%)$ \\
\hline$(50 \%)$ \\
\hline$(52 \%)$ \\
\hline$(52 \%)$ \\
\hline$(55 \%)$ \\
\hline$(55 \%)$ \\
\hline$(60 \%)$ \\
\hline$(60 \%)$ \\
\hline$(62 \%)$ \\
\hline$(64 \%)$ \\
\hline$(64 \%)$ \\
\hline$(69 \%)$ \\
\hline \\
\hline
\end{tabular}

Printable Student Reports for Each Student (this report may take several seconds to open) 
Figure 3. Example of "individual student” page from Dashboard.

\section{Student Results}

Schools Dashboand

Teacher: Demo Teacher

Tection

E. Printeg Friondly

Student: Suzie

\begin{tabular}{|c|c|c|c|}
\hline Question & Correct Answer & Siudent Response & \\
\hline 1 & B & A & \\
\hline 2 & c & c & Correc: \\
\hline 2 & B & A & \\
\hline 4 & A & A & Correct \\
\hline 5 & $A$ & B & \\
\hline 5 & $B$ & 8 & Correct \\
\hline 2 & A & A & Correct \\
\hline$B$ & c & c & Comed \\
\hline 2 & D & c & \\
\hline 10 & $D$ & $\bar{\alpha}$ & ar \\
\hline 11 & A & A & Correct \\
\hline 12 & c & $\mathrm{c}$ & Correct \\
\hline 13 & $c$ & c & Comed \\
\hline 14 & A & c & \\
\hline 15 & A & 8 & $10=$ \\
\hline 16 & 5 & B & Correct \\
\hline 17 & 3 & A & $e^{2}$ \\
\hline 18 & D & c & $12 x=$ \\
\hline 19 & D & D & Coned \\
\hline 20 & c & D & \\
\hline 21 & $D$ & $A$ & 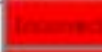 \\
\hline$\underline{22}$ & D & a & thatrot \\
\hline 23 & A & A & Correct \\
\hline 24 & D & D & Correct \\
\hline 25 & B & $B$ & Correct \\
\hline 26 & D & $\mathrm{D}$ & Correct \\
\hline 22 & c & c & Correct \\
\hline$\underline{28}$ & A & A & Correct \\
\hline 29 & A & $B$ & \\
\hline 30 & A & A & Correct \\
\hline 픈 & 5 & 8 & Comect \\
\hline 12 & A & A & Correct \\
\hline$\Delta$ & 2 & 2 & Correct \\
\hline I & 3 & 1 & \\
\hline s & 3 & $\mathrm{t}$ & \\
\hline
\end{tabular}

Click here to see all scores and mastery for this student 
Figure 4. Example of “item” page from Dashboard.

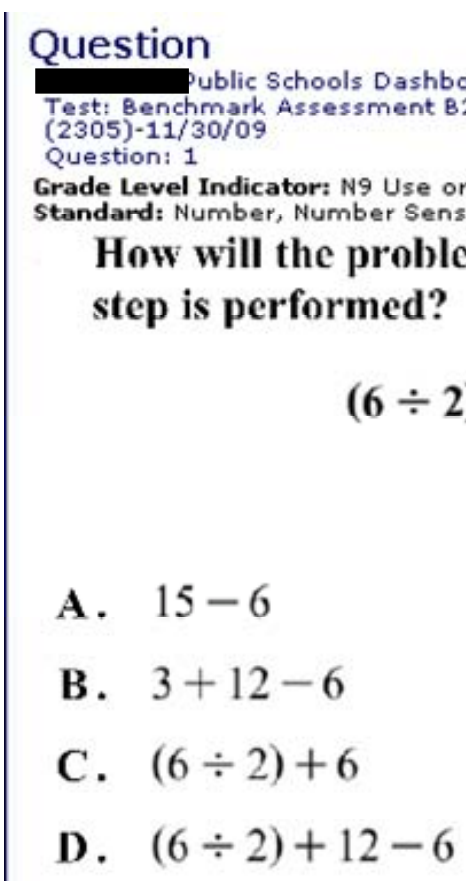


Figure 5. Example of "resource” page from Dashboard.

\begin{tabular}{|c|c|c|c|}
\hline MA & 05 & $\begin{array}{l}\text { Number, Number } \\
\text { Sense and } \\
\text { Operations }\end{array}$ & N2 Use various forms of "one" to demonstrate the equivalence of fractions; e. 9 ., $18 / 24=9 / 12 \times 2 / 2=3 / 4 \times 6 / 6$. \\
\hline MA & 05 & $\begin{array}{l}\text { Number, Number } \\
\text { Sense and } \\
\text { Operations }\end{array}$ & N3 Identify and generate equivalent forms of fractions, decimals and percents. \\
\hline MA & 05 & $\begin{array}{l}\text { Number, Number } \\
\text { Sense and } \\
\text { Operations }\end{array}$ & N4 Round decimals to a given place value and round fractions (including mixed numbers) to the nearest half. \\
\hline MA & 05 & $\begin{array}{l}\text { Number, Number } \\
\text { Sense and } \\
\text { Operations }\end{array}$ & NS Recognize and identify perfect squares and their roots. \\
\hline MA & 05 & $\begin{array}{l}\text { Number, Number } \\
\text { Sense and } \\
\text { Operations }\end{array}$ & $\begin{array}{l}\text { N6 Represent and compare numbers less than } 0 \text { by extending the number line and usina familiar applications: e. } 9 \text {., temperature, owing } \\
\text { money. }\end{array}$ \\
\hline MA & 05 & $\begin{array}{l}\text { Number, Number } \\
\text { Sense and } \\
\text { Operations }\end{array}$ & N7 Use commutative, associative, distributive, identity and inverse properties to simplify and perform computations. \\
\hline MA & 05 & $\begin{array}{l}\text { Number, Number } \\
\text { Sense and } \\
\text { Operations }\end{array}$ & N8 Identify and use relationships between operations to solve problems. \\
\hline MA & 05 & $\begin{array}{l}\text { Number, Number } \\
\text { sense and } \\
\text { Operations }\end{array}$ & N9 Use order of operations, including use of parentheses, to simplify numerical expressions. \\
\hline MA & os & $\begin{array}{l}\text { Number, Number } \\
\text { Sense and } \\
\text { Operations }\end{array}$ & N10 Justify why fractions need common denominators to be added or subtracted. \\
\hline MA & os & $\begin{array}{l}\text { Number, Number } \\
\text { Sense and } \\
\text { Operations }\end{array}$ & $\begin{array}{l}\text { N11 Explain how place value is related to addition and subtraction of decimals; e. } 9 ., 0.2+0.14 \text {; the two tenths is added to the one tenth } \\
\text { because they are both tenths. }\end{array}$ \\
\hline MA & 05 & $\begin{array}{l}\text { Number, Number } \\
\text { Sense and } \\
\text { Operations }\end{array}$ & $\begin{array}{l}\text { N12 Use physical models, points of reference, and equivalent forms to add and subtract commonly used fractions with like and unlike } \\
\text { denominators and decimals. }\end{array}$ \\
\hline MA & 05 & $\begin{array}{l}\text { Number, Number } \\
\text { Sense and } \\
\text { Operations }\end{array}$ & N13 Estimate the results of computations involvinq whole numbers, fractions and decimals, using a variety of strategies. \\
\hline MA & 05 & Measurement & M1 Identify and select appropriate units to measure angles; i.e., degrees. \\
\hline MA & 05 & Measurement & $\begin{array}{l}\text { M2 Identify paths between points on a arid or coordinate plane and compare the lenqths of the paths; e.q., shortest path, paths of equal } \\
\text { length. }\end{array}$ \\
\hline
\end{tabular}

\section{Learning Experiences}

\section{Model Lesson 1}

Intervention Strategies

Custom Test For This Standard

Additional Resources (D3A2) 
Figure 6. Percentage of district teachers who logged into Dashboard by week.

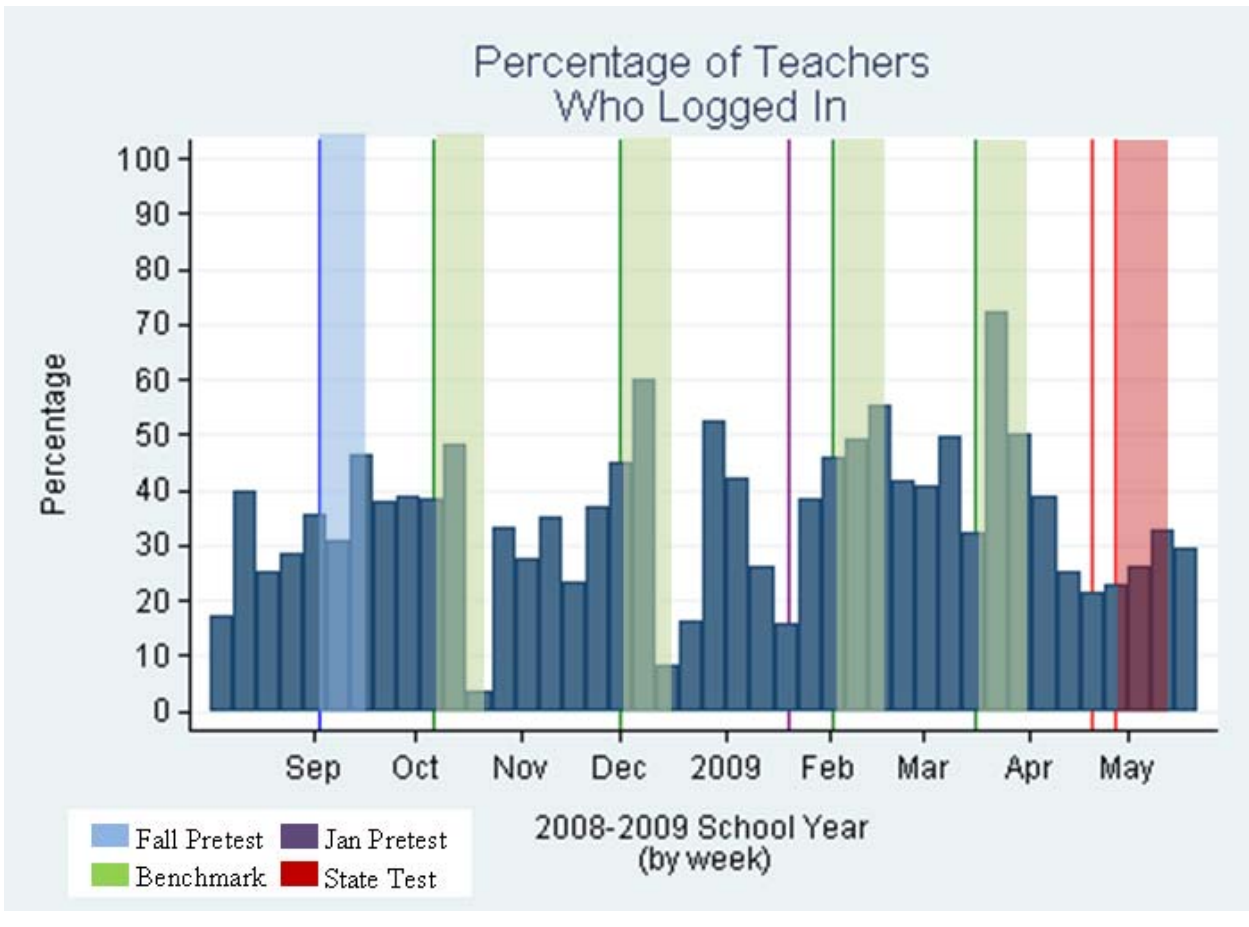

Figure 7. Median time logged in among teachers who ever logged into Dashboard during a week, by week.

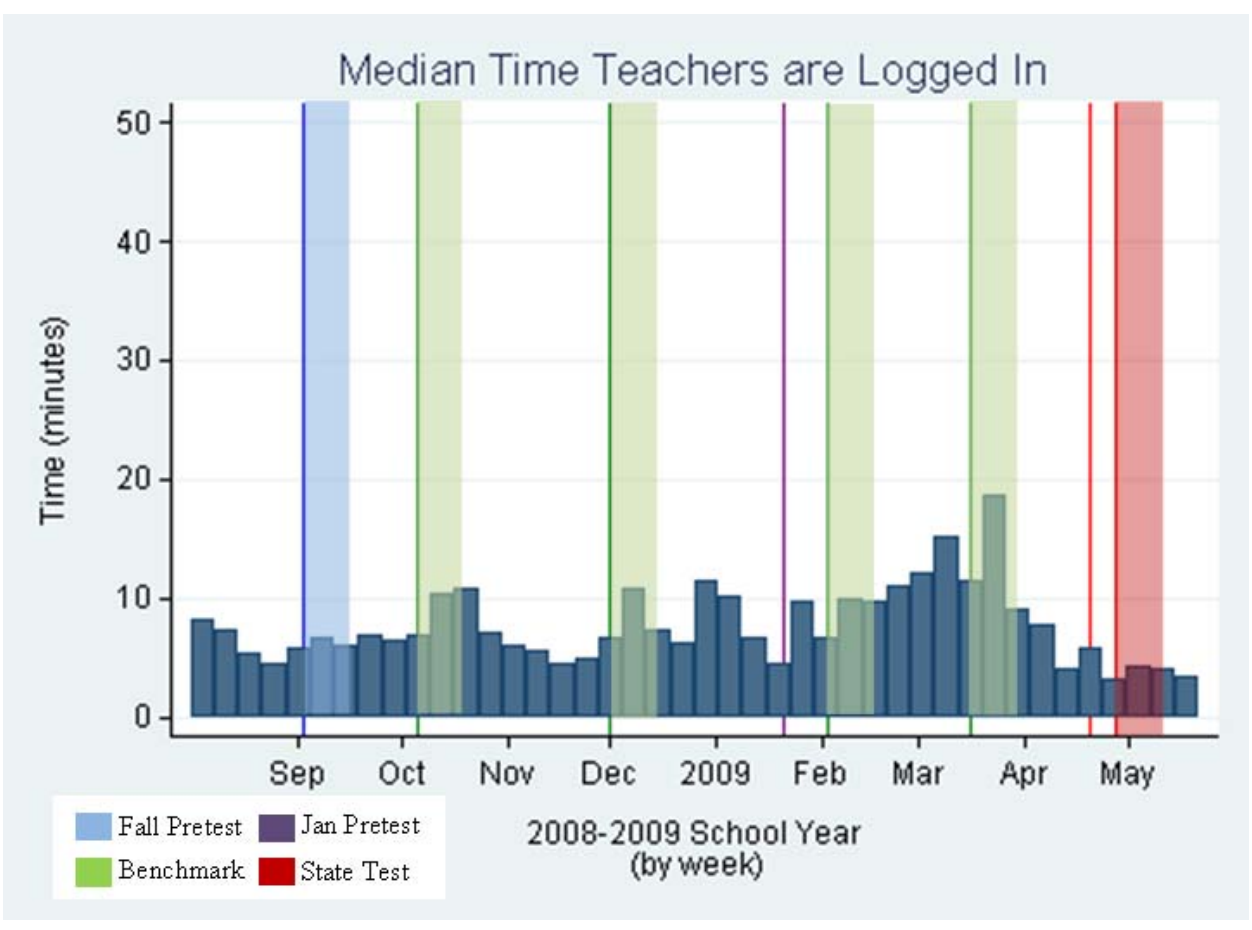


Figure 8. Mean time spent on "students" pages by week.

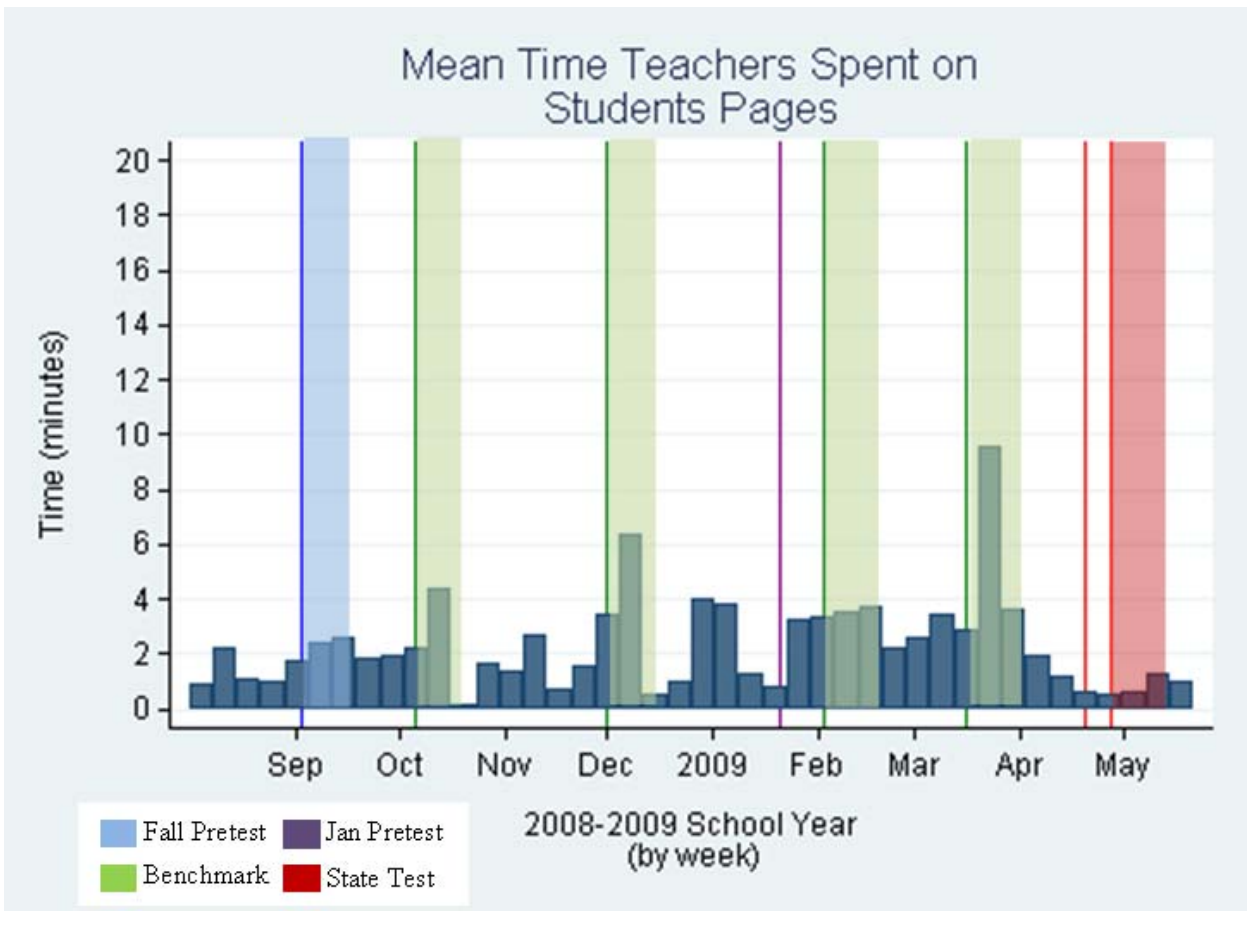

Figure 9. Mean time spent on “individual student” pages by week.

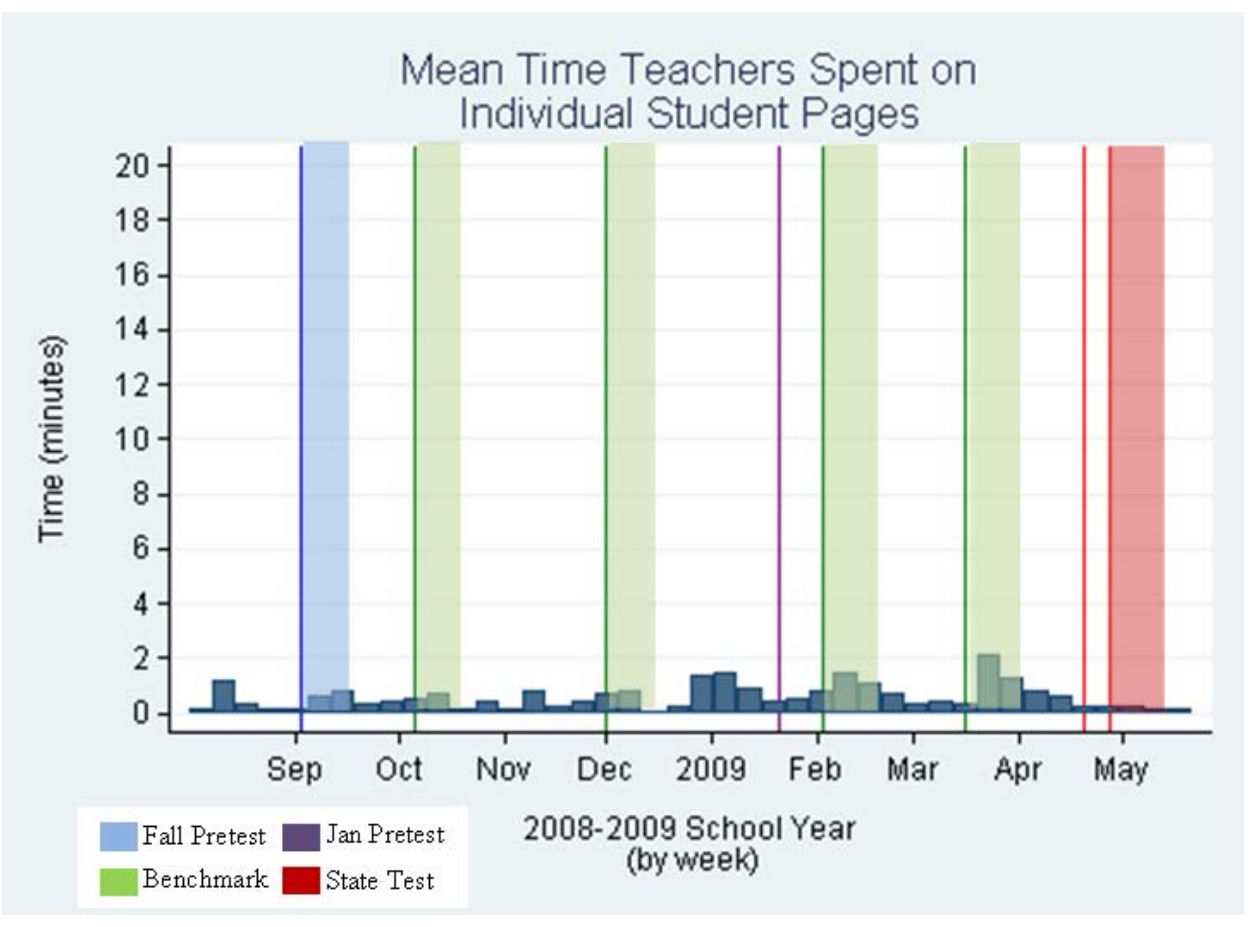


Figure 10. Proportion of total login time spent on "students" and “individual students" pages.

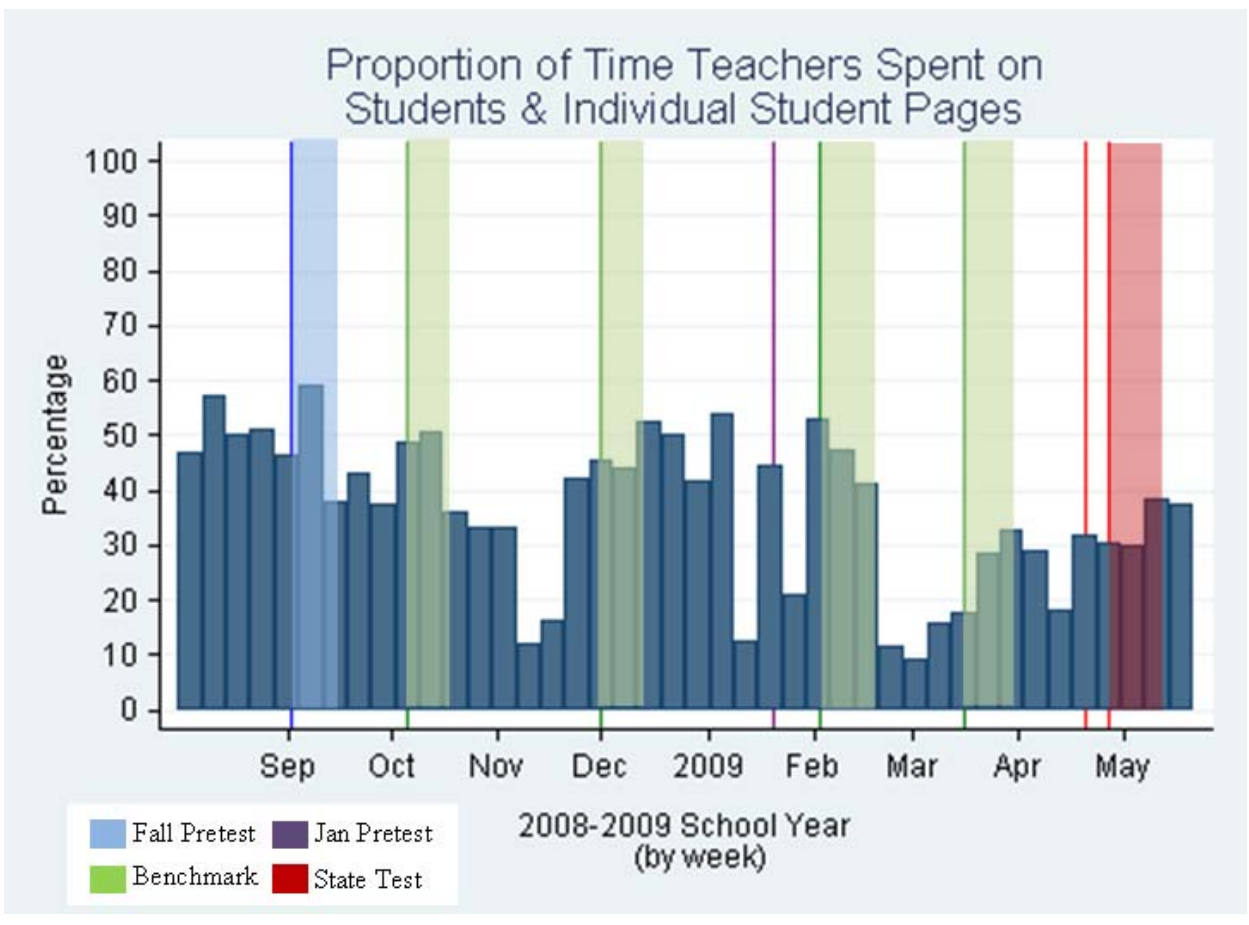

Figure 11. Comparisons of mean viewing page hits versus mean printing page hits for "students" and "individual student" pages by week.

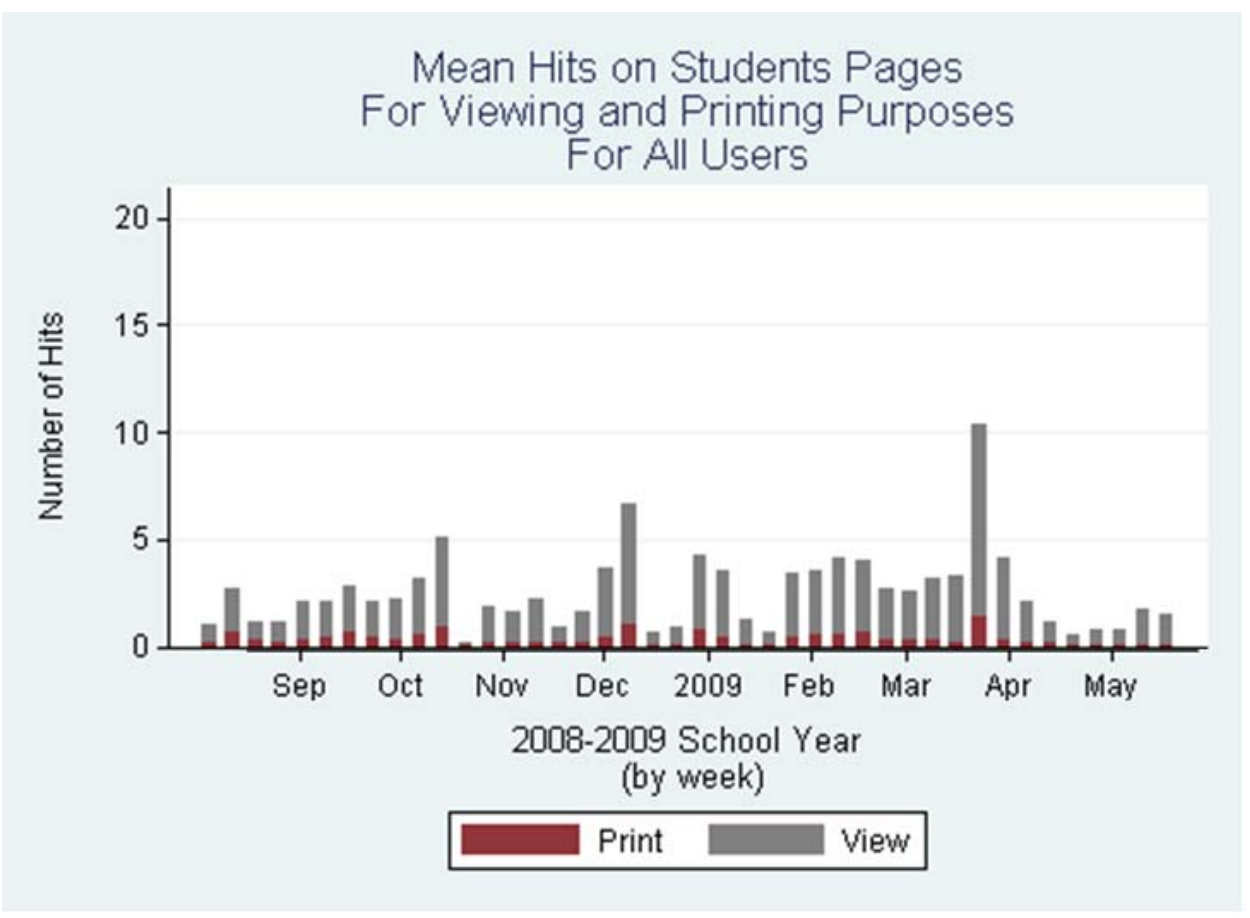


Figure 12. Distribution of total time spent on "students" and "individual student" pages during the 2008-2009 school year.

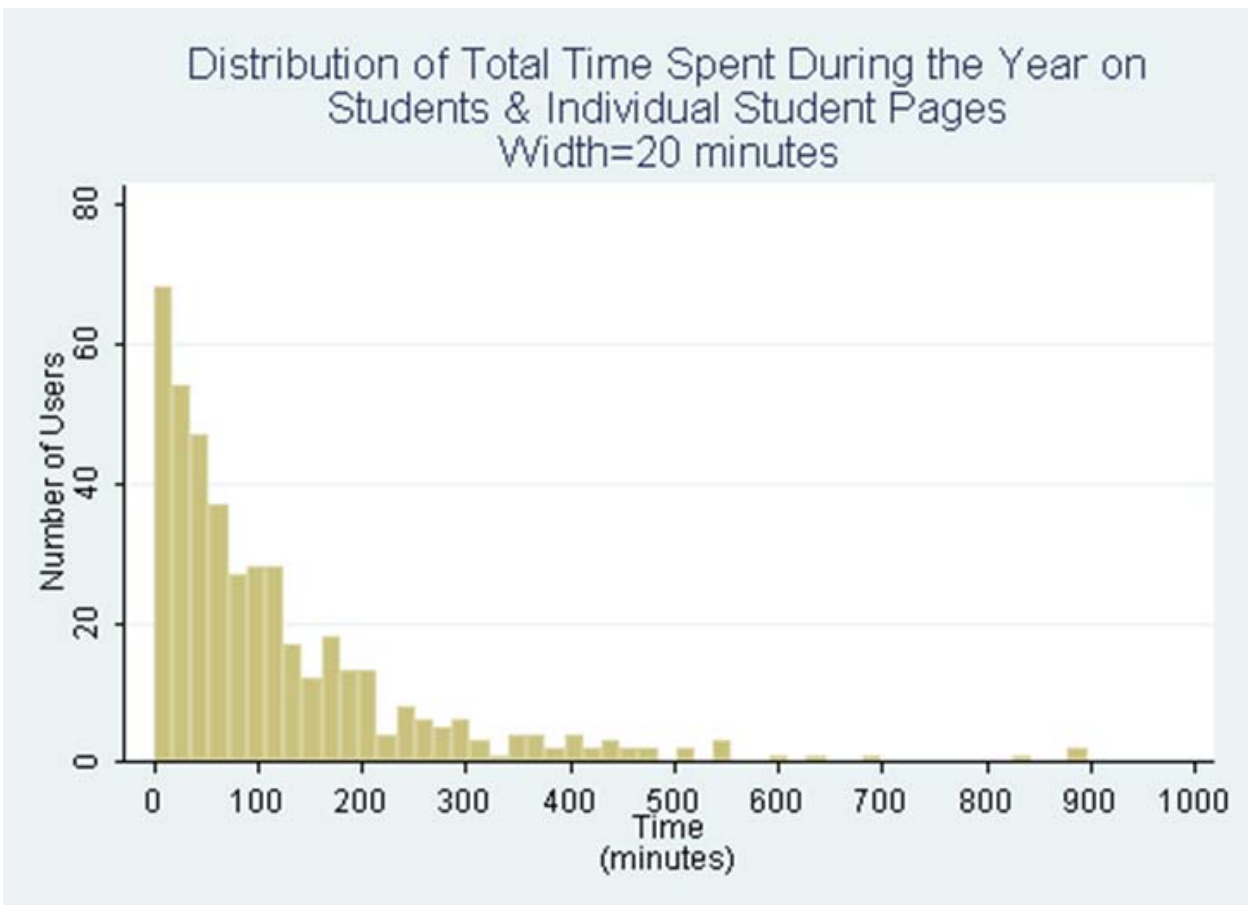


Figure 13. Benchmark math test score by teacher time on that student on Dashboard.

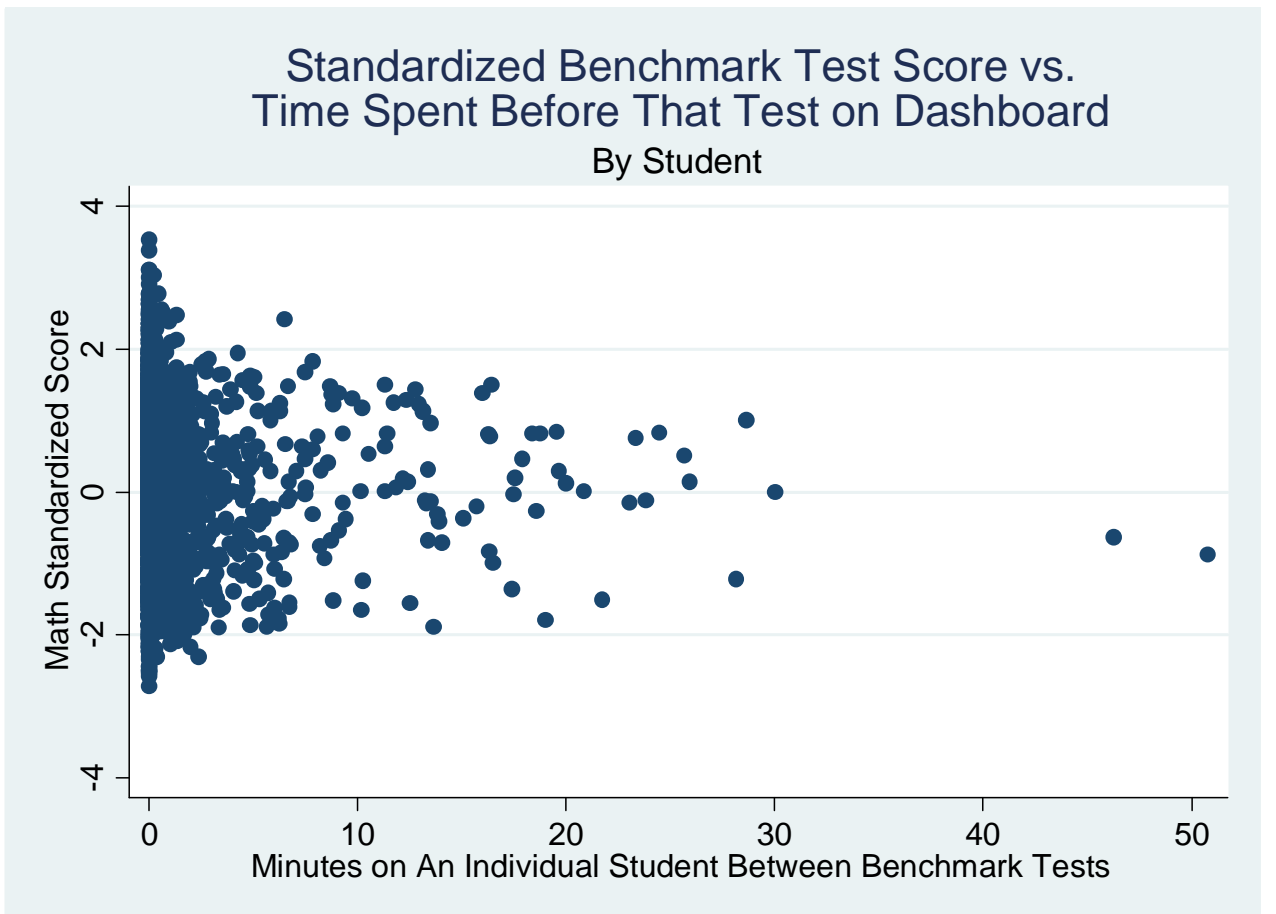

Figure 14. Benchmark ELA test score by teacher time on that student on Dashboard.

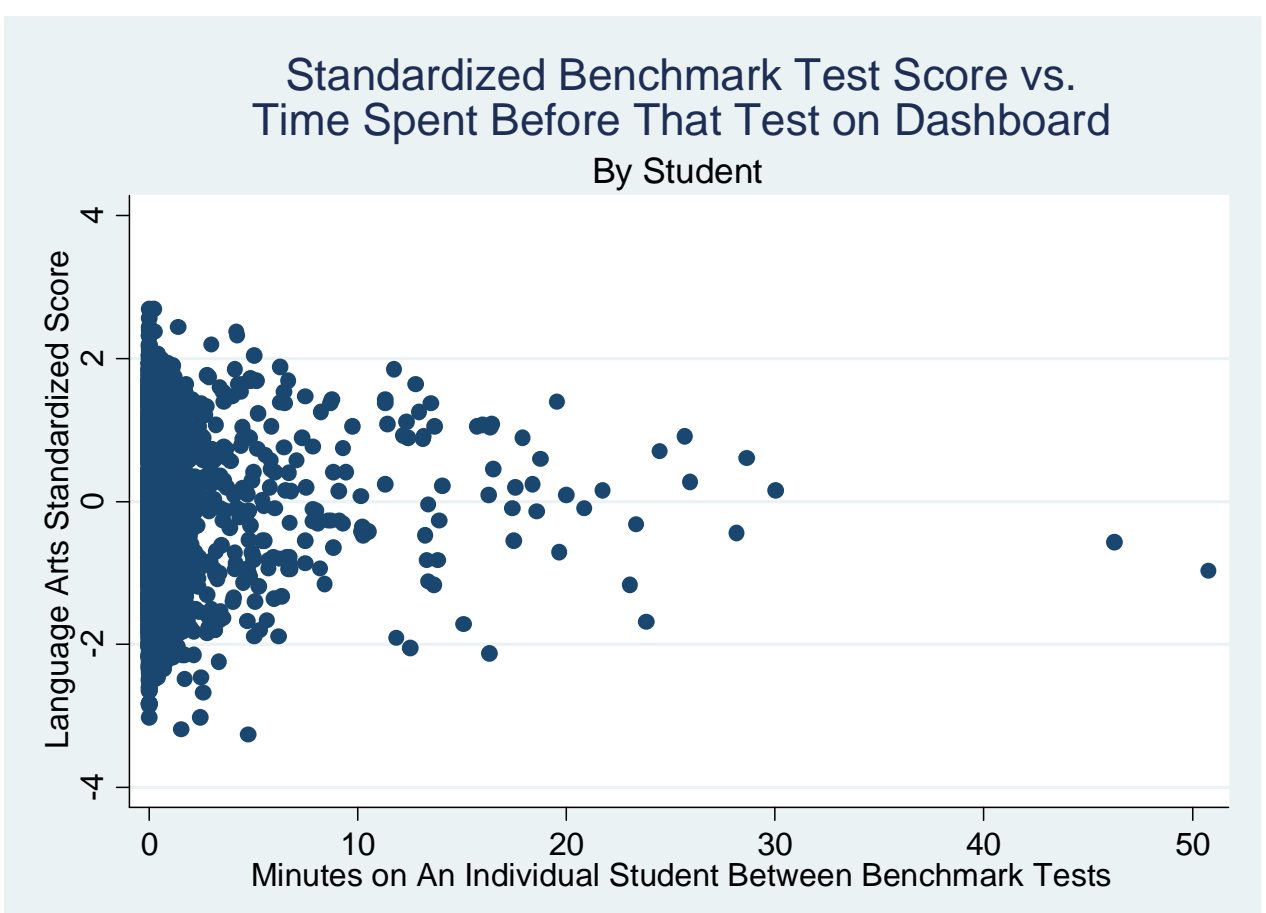


Table 1. Descriptive statistics on various per week Dashboard usage measures for all teachers and conditional on teachers who have non-zero values of the measure under consideration (all time is in minutes).

\begin{tabular}{cc}
\hline \hline All Teachers & $\begin{array}{c}\text { Conditional on } \\
\text { having a non-zero } \\
\text { value }\end{array}$ \\
\hline
\end{tabular}

Panel A: Dashboard logins

$\begin{array}{lcc}\text { Average \# logins } & 0.79 & 2.22 \\ & (1.60) & (2.01) \\ \text { Mean time logged in } & 9.99 & 28.29 \\ & (115.38) & (192.78)\end{array}$

Panel B: Performance

information pages

$\begin{array}{lcc}\text { Mean time on class pages } & 0.25 & 2.84 \\ & (2.03) & (6.20) \\ \text { Mean time on student } & 2.31 & 7.64 \\ \text { pages } & (8.37) & (13.83) \\ & & \\ \text { Mean time on individual } & 0.60 & 6.33 \\ \text { student page } & (5.14) & (15.58) \\ & 0.28 & 2.97 \\ \text { Mean hits on class pages } & (1.31) & (3.19) \\ & 2.52 & 8.22 \\ \text { Mean hits on student pages } & (6.70) & (9.98) \\ & & 5.69 \\ \text { Mean hits on individual } & 0.58 & (12.41) \\ \text { student pages } & (4.32) & \end{array}$

Panel C: Resource-type pages

Mean time on item pages

Mean time on resource

Mean hits on item pages

Mean hits on resource

0.33 
pages

Panel D: Printing performance information pages

Mean hits on print class

0.04

2.66

pages

(0.46)

(2.42)

Mean hits on print

0.35

4.04

students-in-class pages

(1.56)

(3.63)

Mean hits on print

individual student pages

0.16

3.77

(1.71)

(7.56)

Panel E: Printing resource-type pages

Mean hits on print item

0.13

10.83

pages

(3.41)

(29.36)

Mean hits on print resource

0.00

4.00

pages

(0.14)

(4.82) 
Table 2. OLS estimates from regressions with log total time during the year spent on "students" and/or "individual student" level pages as the dependent.

\begin{tabular}{|c|c|c|}
\hline & (1) & (2) \\
\hline $\begin{array}{l}\text { Baseline average student } \\
\text { achievement level }\end{array}$ & $\begin{array}{l}-0.464^{\sim} \\
(0.255)\end{array}$ & $\begin{array}{c}0.081 \\
(0.260)\end{array}$ \\
\hline Value-added estimate & $\begin{array}{c}0.040 \\
(0.619)\end{array}$ & $\begin{array}{l}-0.133 \\
(0.633)\end{array}$ \\
\hline Elementary grade teacher & $\begin{array}{l}-0.413^{*} \\
(0.199)\end{array}$ & $\begin{array}{l}-0.304^{\sim} \\
(0.181)\end{array}$ \\
\hline Female & $\begin{array}{c}0.072 \\
(0.237)\end{array}$ & $\begin{array}{c}0.023 \\
(0.222)\end{array}$ \\
\hline Black & $\begin{array}{c}0.116 \\
(0.197)\end{array}$ & $\begin{array}{l}-0.028 \\
(0.384)\end{array}$ \\
\hline Hispanic or Asian & $\begin{array}{l}-0.951 \\
(0.903)\end{array}$ & $\begin{array}{l}-0.981 \\
(0.682)\end{array}$ \\
\hline Years of experience & $\begin{array}{l}-0.006 \\
(0.010)\end{array}$ & $\begin{array}{c}0.001 \\
(0.010)\end{array}$ \\
\hline Bachelors degree plus & $\begin{array}{l}-0.271 \\
(0.340)\end{array}$ & $\begin{array}{l}-0.272 \\
(0.384)\end{array}$ \\
\hline Masters degree & $\begin{array}{l}-0.181 \\
(0.334)\end{array}$ & $\begin{array}{l}-0.133 \\
(0.363)\end{array}$ \\
\hline Masters degree plus & $\begin{array}{l}-0.296 \\
(0.363)\end{array}$ & $\begin{array}{l}-0.290 \\
(0.398)\end{array}$ \\
\hline School fixed effect & No & Yes \\
\hline $\begin{array}{l}\mathrm{N} \\
\mathrm{R} \text {-squared }\end{array}$ & $\begin{array}{c}325 \\
0.079\end{array}$ & $\begin{array}{c}325 \\
0.151\end{array}$ \\
\hline
\end{tabular}

Robust standard errors (in parentheses) clustered at the school level.

$*=\mathrm{p}<0.05, \sim=\mathrm{p}<0.10$ 
Table 3. OLS estimates from regressions with log total time during the week spent on "students" and/or "individual student" level pages as the dependent variable (robust standard errors in parentheses).

\begin{tabular}{|c|c|c|c|}
\hline & (1) & (2) & (3) \\
\hline 1 week before a Benchmark exam & $\begin{array}{l}-0.131^{*} \\
(0.063)\end{array}$ & $\begin{array}{l}-0.150^{*} \\
(0.063)\end{array}$ & $\begin{array}{l}-0.155^{*} \\
(0.063)\end{array}$ \\
\hline The week during a Benchmark exam & $\begin{array}{c}0.014 \\
(0.072)\end{array}$ & $\begin{array}{c}-0.043 \\
(0.071)\end{array}$ & $\begin{array}{c}-0.042 \\
(0.071)\end{array}$ \\
\hline 2 weeks after a Benchmark exam & $\begin{array}{l}0.436^{* * *} \\
(0.058)\end{array}$ & $\begin{array}{l}0.412^{* * *} \\
(0.057)\end{array}$ & $\begin{array}{l}0.417^{* * *} \\
(0.058)\end{array}$ \\
\hline 1 week before the state exams & $\begin{array}{c}0.022 \\
(0.103)\end{array}$ & $\begin{array}{c}0.016 \\
(0.103)\end{array}$ & $\begin{array}{c}0.014 \\
(0.102)\end{array}$ \\
\hline 2 weeks during the state exams & $\begin{array}{l}-0.281^{\sim} \\
(0.145)\end{array}$ & $\begin{array}{l}-0.262 \sim \\
(0.145)\end{array}$ & $\begin{array}{l}-0.263^{*} \\
(0.145)\end{array}$ \\
\hline 2 weeks after the state exams & $\begin{array}{c}-0.489^{* * *} \\
(0.127)\end{array}$ & $\begin{array}{c}-0.478^{* * *} \\
(0.127)\end{array}$ & $\begin{array}{l}-0.464^{* *} \\
(0.124)\end{array}$ \\
\hline Teacher and ClassVariables $^{\mathrm{a}}$ & No & Yes & Yes \\
\hline School fixed effect & No & No & Yes \\
\hline Number of teachers & 325 & 325 & 325 \\
\hline Number of observations & 4,385 & 4,385 & 4,385 \\
\hline R squared & 0.027 & 0.062 & 0.080 \\
\hline
\end{tabular}

Standard errors (in parentheses) clustered at the teacher level.

a. Including beginning of year average class achievement level, teacher value-added estimate, years of teaching experience, and indicators for whether an elementary teacher, AfricanAmerican, Hispanic or Asian, whether average student ability was imputed, and education level of teacher.

$* * *=\mathrm{p}<0.001, * *=\mathrm{p}<0.01, *=\mathrm{p}<0.05,{ }^{\sim}=\mathrm{p}<0.10$ 
Table 4. Within teacher estimates of the change in Dashboard usage between 2008-2009 and 2009-2010.

\begin{tabular}{|c|c|c|c|c|}
\hline & $\begin{array}{c}(1) \\
\text { Log minutes on } \\
\text { students-in-class } \\
\text { level data }\end{array}$ & $\begin{array}{c}\text { (2) } \\
\text { Log minutes on } \\
\text { individual-student } \\
\text { level data }\end{array}$ & $\begin{array}{c}\text { (3) } \\
\text { Log number of } \\
\text { times } \\
\text { students-in-class } \\
\text { level data printed }\end{array}$ & $\begin{array}{c}\text { (4) } \\
\text { Log number of } \\
\text { times } \\
\text { individual-student } \\
\text { level data printed }\end{array}$ \\
\hline $\begin{array}{l}2010 \\
\text { indicator }\end{array}$ & $\begin{array}{c}0.234 * \\
(0.0966)\end{array}$ & $\begin{array}{l}0.0124 \\
(0.201)\end{array}$ & $\begin{array}{c}0.197 \\
(0.102)\end{array}$ & $\begin{array}{c}0.322^{\sim} \\
(0.194)\end{array}$ \\
\hline $\begin{array}{l}\text { Targeted } \\
\text { Assistance } \\
\text { (TA) School }\end{array}$ & $\begin{array}{l}0.0535 \\
(0.319)\end{array}$ & $\begin{array}{l}-0.378 \\
(0.616)\end{array}$ & $\begin{array}{c}0.171 \\
(0.321)\end{array}$ & $\begin{array}{l}-0.565 \\
(0.671)\end{array}$ \\
\hline $\begin{array}{l}\text { TA School in } \\
2009-2010\end{array}$ & $\begin{array}{l}-0.239 \\
(0.160)\end{array}$ & $\begin{array}{l}-0.338 \\
(0.324)\end{array}$ & $\begin{array}{l}0.383 * \\
(0.153)\end{array}$ & $\begin{array}{l}0.0726 \\
(0.284)\end{array}$ \\
\hline $\begin{array}{l}\text { Number of } \\
\text { students in } \\
\text { class }\end{array}$ & $\begin{array}{c}-0.00425^{*} \\
(0.00182)\end{array}$ & $\begin{array}{c}-0.00655 \\
(0.00377)\end{array}$ & $\begin{array}{l}-0.000810 \\
(0.00216)\end{array}$ & $\begin{array}{l}-0.00165 \\
(0.00366)\end{array}$ \\
\hline $\begin{array}{l}\text { Average } \\
\text { class } \\
\text { achievement }\end{array}$ & $\begin{array}{c}-0.00643 \\
(0.172)\end{array}$ & $\begin{array}{l}-0.132 \\
(0.344)\end{array}$ & $\begin{array}{l}-0.334 \\
(0.175)\end{array}$ & $\begin{array}{l}-0.447 \\
(0.298)\end{array}$ \\
\hline $\begin{array}{l}\text { Teacher } \\
\text { fixed effects }\end{array}$ & Yes & Yes & Yes & Yes \\
\hline $\begin{array}{l}\text { Number } \\
\text { teachers }\end{array}$ & 243 & 243 & 243 & 243 \\
\hline $\begin{array}{l}\text { Adjusted } \\
\text { R-sq }\end{array}$ & 0.615 & 0.286 & 0.709 & 0.381 \\
\hline
\end{tabular}

Standard errors in parentheses.

$\sim=\mathrm{p}<0.10, *=\mathrm{p}<0.05$ 
Table 5. Student and teacher predictors of how much teachers view the data of individual students in Dashboard.

\begin{tabular}{|c|c|c|c|}
\hline & $\begin{array}{c}\text { (1) } \\
\text { Log minutes on } \\
\text { individual student } \\
\text { data }\end{array}$ & $\begin{array}{c}\text { (2) } \\
\text { Log minutes on } \\
\text { individual student } \\
\text { data }\end{array}$ & $\begin{array}{c}\text { (3) } \\
\text { Log minutes on } \\
\text { individual student } \\
\text { data }\end{array}$ \\
\hline Prior year test score & $\begin{array}{l}-0.0914 * \\
(0.0460)\end{array}$ & $\begin{array}{l}-0.0659^{\sim} \\
(0.0380)\end{array}$ & $\begin{array}{l}-0.0479^{\sim} \\
(0.0245)\end{array}$ \\
\hline $\begin{array}{l}\text { Eligible for gifted \& } \\
\text { talented }\end{array}$ & $\begin{array}{c}0.174 \\
(0.124)\end{array}$ & $\begin{array}{c}0.180 \\
(0.113)\end{array}$ & $\begin{array}{c}0.0599 \\
(0.0824)\end{array}$ \\
\hline English language learner & $\begin{array}{c}0.264 \\
(0.172)\end{array}$ & $\begin{array}{c}0.204 \\
(0.155)\end{array}$ & $\begin{array}{l}0.186^{\sim} \\
(0.109)\end{array}$ \\
\hline Special education & $\begin{array}{c}0.171^{*} \\
(0.0708)\end{array}$ & $\begin{array}{l}0.192 * * \\
(0.0681)\end{array}$ & $\begin{array}{l}0.158 * * * \\
(0.0471)\end{array}$ \\
\hline Teacher characteristics & No & Yes & -- \\
\hline Teacher fixed-effects & No & No & Yes \\
\hline $\begin{array}{l}\text { Number of student } \\
\text { observations }\end{array}$ & 4,106 & 4,106 & 4,106 \\
\hline Number of teachers & 271 & 271 & 271 \\
\hline Adjusted R-sq & 0.007 & 0.017 & 0.302 \\
\hline
\end{tabular}

Standard errors (in parentheses) clustered at the teacher level.

$\sim=\mathrm{p}<0.10, *=\mathrm{p}<0.05, * *=\mathrm{p}<0.01$ 
Table 6. Estimates of the relationship between Benchmark test scores in math and ELA and the amount of time spent by the teacher viewing the student's data in the just prior interval between the last and the current Benchmark test.

\begin{tabular}{|c|c|c|c|c|}
\hline & $\begin{array}{c}\text { (1) } \\
\text { Math } \\
\text { Benchmark }\end{array}$ & $\begin{array}{c}\text { (2) } \\
\text { Math } \\
\text { Benchmark }\end{array}$ & $\begin{array}{c}\text { (4) } \\
\text { ELA } \\
\text { Benchmark }\end{array}$ & $\begin{array}{c}\text { (5) } \\
\text { ELA } \\
\text { Benchmark }\end{array}$ \\
\hline $\begin{array}{l}\text { Minutes of teacher } \\
\text { Dashboard time on } \\
\text { student in just prior } \\
\text { Benchmark test interval }\end{array}$ & $\begin{array}{c}-0.00640 \\
(0.005667)\end{array}$ & $\begin{array}{l}-0.00862 \\
(0.00472)\end{array}$ & $\begin{array}{l}-0.00339 \\
(0.00351)\end{array}$ & $\begin{array}{l}-0.00403 \\
(0.00406)\end{array}$ \\
\hline Prior test score & $\begin{array}{c}0.627 * * * \\
(0.0151)\end{array}$ & $\begin{array}{c}0.583 * * * \\
(0.0141)\end{array}$ & $\begin{array}{c}0.618 * * * \\
(0.0172)\end{array}$ & $\begin{array}{l}0.588 * * * \\
(0.0140)\end{array}$ \\
\hline $\begin{array}{l}\text { Eligible for gifted \& } \\
\text { talented }\end{array}$ & $\begin{array}{c}0.225 * * * \\
(0.053)\end{array}$ & $\begin{array}{l}0.276 * * * \\
(0.0378)\end{array}$ & $\begin{array}{c}0.240 * * * \\
(0.0343)\end{array}$ & $\begin{array}{c}0.294^{* * *} \\
(0.0343)\end{array}$ \\
\hline $\begin{array}{l}\text { English language } \\
\text { learner }\end{array}$ & $\begin{array}{l}0.0405 \\
(0.0552)\end{array}$ & $\begin{array}{c}0.0671 \\
(0.0596)\end{array}$ & $\begin{array}{c}0.0450 \\
(0.0749)\end{array}$ & $\begin{array}{c}0.0720 \\
(0.0617)\end{array}$ \\
\hline Special education & $\begin{array}{l}-0.144 * * * \\
(0.0346)\end{array}$ & $\begin{array}{l}-0.132 * * * \\
(0.0308)\end{array}$ & $\begin{array}{c}-0.156 * * * \\
(0.0271)\end{array}$ & $\begin{array}{c}-0.1868 * * * \\
(0.0304)\end{array}$ \\
\hline Students in class & $\begin{array}{c}0.001080 \\
(0.000652)\end{array}$ & -- & $\begin{array}{c}0.000734 \\
(0.000738)\end{array}$ & -- \\
\hline $\begin{array}{l}\text { Average class } \\
\text { achievement }\end{array}$ & $\begin{array}{l}0.067^{*} \\
(0.034)\end{array}$ & -- & $\begin{array}{l}0.162 * * * \\
(0.0263)\end{array}$ & -- \\
\hline $\begin{array}{l}\text { Student gender and } \\
\text { race/ethnicity }\end{array}$ & Yes & Yes & Yes & Yes \\
\hline Teacher characteristics & Yes & -- & Yes & -- \\
\hline Teacher fixed effects & No & Yes & No & Yes \\
\hline $\begin{array}{l}\text { Number of student- } \\
\text { interval observations }\end{array}$ & 5,652 & 5,652 & 5,644 & 5,644 \\
\hline Number of teachers & 149 & 149 & 150 & 150 \\
\hline Adjusted R-sq & 0.4923 & 0.505 & 0.494 & 0.497 \\
\hline
\end{tabular}

Standard errors (in parentheses) clustered the teacher level.

$* *=\mathrm{p}<0.01, * * *=\mathrm{p}<0.001$ 